
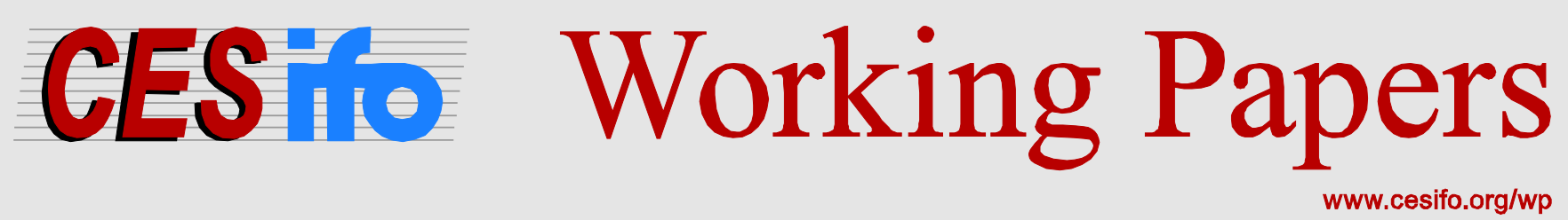

\title{
Pocketbook Voting and Social Preferences in Referenda
}

\author{
Johannes Meya \\ Panu Poutvaara \\ Robert Schwager
}

CESIFO WORKING PAPER NO. 5267

CATEgory 2: Public CHOICE

MARCH 2015

An electronic version of the paper may be downloaded

- from the SSRN website:

- from the RePEc website:

- from the CESifo website:

WwW.SSRN.com

Www.RePEc.org

www.CESifo-group.org/wp 


\title{
Pocketbook Voting and Social Preferences in Referenda
}

\begin{abstract}
We study the role of self-interest and social preferences in referenda. Our analysis is based on collective purchasing decisions of university students on deep-discount flat rate tickets for public transportation and culture. Individual usage data allows quantifying monetary benefits associated with each ticket. We find that turnout is much higher among students who benefit a lot from having a ticket, suggesting instrumental voting. In each referendum, a majority votes in line with self-interest, providing strong evidence for pocketbook voting. However, social preferences like altruism, public good considerations and paternalism shift the vote of a sizable minority against their own financial interest.
\end{abstract}

JEL-Code: D720, H410, D640.

Keywords: pocketbook voting, social preferences, altruism, instrumental voting, public goods, referendum.

\author{
Johannes Meya \\ Chair of Public Economics \\ Georg-August University Goettingen \\ Platz der Goettinger Sieben 3 \\ Germany-37073 Goettingen \\ jmeya@uni-goettingen.de
}

\author{
Panu Poutvaara \\ Ifo Institute - Leibniz Institute for \\ Economic Research \\ at the University of Munich \\ Poschingerstrasse 5 \\ Germany-81679 Munich \\ poutvaara@ifo.de
}

\author{
Robert Schwager \\ Chair of Public Economics \\ Georg-August University Goettingen \\ Platz der Goettinger Sieben 3 \\ Germany - 37073 Goettingen \\ rschwag@uni-goettingen.de
}

March 2015

We thank Thushyanthan Baskaran, Mikael Elinder, Ingo Geishecker, Henrik Jordahl and Martin Kocher for helpful comments, Felix Albrecht for research assistance, and everyone who helped in the data collection. Johannes Meya and Robert Schwager gratefully acknowledge financial support by the German Federal Ministry of Education and Research under grant number 01PW11004. Responsibility for the content remains with the authors. 


\section{Introduction}

Referenda are an integral part of democracy in several jurisdictions, such as Switzerland and California. For example, by bounding the property tax rate, Proposition 13 in 1978 decisively shaped local public finances in California (see California State Board of Equalization, 2012, p. 1). On the expenditure side, major examples include referenda on the Gotthard train tunnel in Switzerland in 1992 or on the high-speed railway in California (Proposition 1A) in 2008. In other countries, referenda have usually been restricted to constitutional issues such as membership in the European Union. In recent years, however, an increasing number of countries have also held referenda on non-constitutional issues, in particular public infrastructure projects. For instance, local referenda on transportation took place in 2005 (Edinburgh road tolls referendum) and in 2008 (Greater Manchester transport referendum) in the United Kingdom, Italy voted on nuclear power and water service tariffs in 2011, and a German state held a referendum on a major railway project (Stuttgart 21) in 2011.

Despite their increasing popularity, referenda, and in particular those on fiscal issues, are controversial. Proponents welcome the broad public debate and the democratic legitimacy of decisions ensured by referenda. In this spirit, Rousseau (2012 [1762], p. 65) argued already 250 years ago: "Every law the people has not ratified in person is null and void - is, in fact, not a law." Opponents fear that uninformed or ideologically biased citizens either do not bother to turn out or end up making inefficient or inequitable decisions. Schumpeter (1994 [1942], p. 261) was convinced that "[the private citizen] expends less disciplined effort on mastering a political problem than he expends on a game of bridge." The present paper contributes to this debate by empirically analyzing the motives for participating in a referendum and for voting against or in favor of a proposal. Our results show that 'pocketbook voting', that is voting along monetary interests, is predominant. However, social considerations such as the benefits and costs of other voters or the promotion of some common good are also present, and sometimes even pivotal.

We consider referenda on flat rate tickets for students at Goettingen University in Germany. If passed, such a ticket gives all students the right to unlimited use of some facility such as public transportation or cultural amenities. The price of the ticket is very attractive compared to individual purchases, but buying the ticket becomes compulsory for every student once the majority voted in favor. Such tickets therefore share essential features of tax-financed public projects like the examples mentioned above. By collectively procuring the ticket, per capita cost of the respective facility are reduced so that frequent users stand to gain substantially from an approval by the majority. At the same time, some voters will use the facility in question very 
little or not at all, but are still forced to pay as much for it as anyone else.

Investigating these referenda is particularly promising since they refer to easyto-understand public policy decisions. In particular, in our setting, voters knew exactly what a ticket would cost and benefits were clearly defined. Opposed to that, if the vote took place, say, on a big infrastructure project, costs and benefits would be uncertain. Different voting decisions could also then reflect different subjective expectations on possible deviations from projections and differences in risk attitudes. In this sense, the referenda we study are like a 'laboratory' for direct democratic decisions, where confounding influences are reduced to a minimum.

Our main dataset covers votes on tickets for regional trains, cultural facilities and local buses, taken in 2013. The second dataset is on a referendum about a train ticket, held in 2010. Our analysis is based on two surveys conducted after the votes. Whereas the survey in 2013 was a paper-based exit poll, the dataset from 2010 was collected online. Therefore, this second dataset also encompasses students who did not participate in the referendum, allowing for the analysis of the turnout decision.

Both datasets contain detailed information about usage behavior, votes, political preferences and other characteristics of more than a thousand respondents each. In the main dataset, usage is reported in categorical variables. In the second dataset, we construct a detailed monetary measure of individual benefits conferred by the ticket. To do so, we combine information on the number of trips to parents with regular ticket prices that we derive from parental address data. Additionally, students were asked to what extent the interests of others shaped their voting decision. Further motives include social or political goals, such as promoting local cultural life and expressing protest against the pricing policy of the rail company.

Our primary focus is on the probability of voting in favor of a ticket. We find strong evidence for pocketbook voting. Most students voted in line with monetary interests. In the main dataset, a student who uses a facility very often is between 52 and 76 percentage points more likely to vote in favor of the corresponding ticket than one who never uses it. In the second dataset, a 10 percent increase in cost savings conferred by the train ticket raises the probability of voting in favor by 0.7 to 0.8 percentage points. This translates into widely differing predictions, given that savings vary between zero and more than three thousand euros per year.

However, our results show that monetary self-interest is not the whole story. While party preferences are mostly not relevant for the voting decision, variables capturing social preferences, such as altruism and merit good considerations, show highly significant and economically relevant effects. A sizeable share of students who do not gain in monetary terms from a ticket voted in favor because of such motives. The analysis suggests that social preferences were likely pivotal in one out of four referenda and were close to being pivotal in another one. Pocketbook voting and 
social preferences together can rationalize almost all votes cast.

In the second part of the paper, the dependent variable is participation in the referendum. We find that the probability of taking part increases in individual stakes, measured by the absolute value of the difference between the benefits conferred by the ticket and its price. This suggests some degree of instrumental turnout. Furthermore, our analysis shows that students with very large positive benefits drive this result. Additionally, there is evidence that some students did turn out in order to protest against the train company's pricing policy.

Our paper contributes to the literature on the motives of voters. A central question in this literature is to what extent citizens vote according to their narrowlydefined self-interest and to what extent voting decisions are driven by social considerations.

Pocketbook voting is the starting point in models of income redistribution building on Meltzer and Richard (1981), in the theory of probabilistic voting (Lindbeck and Weibull, 1993; Dixit and Londregan, 1996) and in median voter models of local public finance (Romer et al., 1992; Epple and Romano, 1996; Epple et al., 2001). Several authors specifically aim at empirically detecting this motive in referenda. In an early contribution, Deacon and Shapiro (1975) find that voters in cities connected to the BART transport system in the San Francisco area were more likely to favor a proposition which would shift petrol tax revenues to public transportation. Similarly, voters in precincts which are located close to sports stadiums are more positive towards subsidizing them (Coates and Humphreys, 2006). Intriguingly, according to Potrafke (2013), this does not hold for concert halls. Vlachos (2004) concludes that voting patterns in the Swedish referendum on the EU membership are in line with conflicting regional interests. Similar to these authors, we find evidence for pocketbook voting, but we go further by analyzing individual voting and turnout decisions rather than relying on regional vote shares.

Even more importantly, we study the role of social preferences, which has so far been neglected in the analysis of real world referenda. This contrasts with experimental studies on voting behavior which typically find that in addition to monetary self-interest, voting reflects various kinds of social preferences. In particular, Tyran and Sausgruber (2006) show that inequity aversion in the sense of Fehr and Schmidt (1999) is important in laboratory elections. Introducing a novel random price voting mechanism, Messer et al. (2010) conclude that subjects' behavior is better explained by pure altruism than by inequity aversion. Balafoutas et al. (2013) find that while voting on redistribution is mostly predicted by self-interest, there is greater support for redistribution when inequalities are arbitrary than when they reflect performance in an experimental task. This is in line with what Fong (2001) and Alesina and Angeletos (2005) derive from survey evidence. 
Literature on economic voting has mostly focused on representative democracy. Lewis-Beck and Stegmaier (2007) survey more than 400 studies without finding much evidence for pocketbook voting. Most of the studies in their analysis suffer from severe identification problems: they assume that voters attribute all changes in their financial situation to the policies of the incumbent government. When analyzing well-defined past policies, Levitt and Snyder (1997), Richter (2006), Manacorda et al. (2011), Kriner and Reeves (2012), Pop-Eleches and Pop-Eleches (2012), De La O (2013) and Zucco (2013) find that voters increase their support to the government if they have benefited from its transfers in the past. Thachil (2014) shows that poor people vote for elite parties because organizations linked to these parties provide them local public services. Elinder et al. (2015) find strong evidence for prospective pocketbook voting: voters already react when reforms appear as electoral promises.

In general, it should be noted that pocketbook voting does not exclude taking into account also what is good for others. Fiorina (1978) and Markus (1988) conclude that both self-interest and conviction on what is good for the society matter for American voters. In Sweden, most survey respondents admitted that own interest mattered either as much as conviction or more when they chose the party to vote for (Carlsson and Johansson-Stenman, 2010).

We also contribute to the literature on voter turnout. Already Downs (1957) and Riker and Ordeshook (1968) presented the idea that the more is at stake, the more likely an individual should vote. Indeed, Andersen et al. (2014) observe that turnout in Norwegian local elections is higher in jurisdictions with high hydropower income. Alternative explanations suggest that voting is driven by ethical concerns (Harsanyi, 1980; Coate and Conlin, 2004), social pressure (Gerber et al., 2008; Funk, 2010), or expressive motivations (Brennan and Buchanan, 1984; Brennan and Hamlin, 1998; Coate et al., 2008; Hillman, 2010). We also find that the likelihood of participating increases in the personal stake. However, there is also evidence that some voters turned out to protest against the train company's pricing policy. This behavior can be tactical in order to improve students' bargaining position. Alternatively, it can be motivated by expressive concerns.

A number of studies have found that voting decisions react to national economic conditions. Seminal contributions to this literature include Key (1966), Barro (1973), Kinder and Kiewiet (1979), Fiorina (1981), and Rogoff and Sibert (1988). Since good economic conditions generally also benefit the individual voter, such sociotropic voting may reflect self-interest or altruism. Recently, Margalit (2013) and Ansell (2014) have shown that those personally affected by macroeconomic developments adjust their attitude towards redistributive policies. While our setting is unrelated to macroeconomic performance, our analysis complements this line of work by distinguishing between pocketbook voting and various social preferences. 
Finally, our paper is also broadly related to the literature which investigates the impact of direct democracy on the public budget. Referenda are associated with lower public spending both in the US (Matsusaka, 1995) and in Switzerland (Feld and Kirchgässner, 2001; Feld and Matsusaka, 2003; Funk and Gathmann, 2011). The focus of our paper differs from these contributions in that we do not aim at comparing direct and representative democracy. Nevertheless, our finding that those who benefit most are most likely to vote suggests that direct democracy does not necessarily result in underspending.

The remainder of the paper is structured as follows. Section 2 presents the data and some background information. In Section 3, we give a descriptive overview of voting motives. Econometric results on the voting and participation decisions are presented in Sections 4 and 5 respectively. Section 6 concludes.

\section{Data}

\subsection{Institutional background and data collection}

Goettingen University periodically holds referenda among students on whether they should collectively purchase flat rate tickets, called 'Semestertickets'. Such a ticket gives all students of the university the right to use some specific service as often as they wish. The price of the ticket is very attractive compared to prices for individual use, but once a ticket is accepted in the referendum, its price is collected as part of the registration fee from all students with only very few exemptions.

Referenda are usually held yearly during at least three consecutive days in January at several locations on campus, and postal vote is possible. For accepting a ticket, a double threshold must be passed: at least $50 \%$ of votes must be in favor of the ticket and, at the same time, at least $15 \%$ of students must vote in favor.

We analyze votes on tickets for regional trains, local buses, and cultural amenities. The main dataset, which we label Dataset I in the following, is based on a survey related to referenda on all three tickets which took place in January 2013. The bus ticket would be valid on all buses within Goettingen and two nearby villages. The culture ticket offers free or highly discounted entrance to a number of cultural institutions and events such as theaters, museums and concerts. The train ticket, which is described in more detail below, grants free travel on local trains. The train ticket had been in place without interruption since 2004, the cultural ticket was introduced in October 2012, while the bus ticket would have been a novelty.

The prices per semester amounted to 8.55 euros for the cultural ticket, 25.80 euros for the bus ticket and 95.04 euros for the train ticket. About 36\% of almost 25,600 students took part in each referendum, and two out of three referenda were close. 
While the culture ticket just passed with $53 \%$ approval, the bus ticket failed with $46 \%$ support. An overwhelming majority of $82 \%$ voted in favor of the train ticket.

Dataset I was collected using exit polls. After leaving the polling place, students were approached by members of the survey team and asked to take part in a paper based survey. To preserve anonymity, cubicles similar to polling booths were installed. Participation was incentivized by a lottery with prizes of 200, 100 and 50 euros.

Dataset II was collected after a referendum held in May 2010 on a train ticket only. The ticket cost 42.24 euros per semester and differed in scope from the one voted on in 2013, as explained below. Of about 22,800 students registered at that time, $24 \%$ participated in the referendum, thereof $82 \%$, voting yes.

In order to obtain data on the voting and traveling behavior of students an anonymous online survey was conducted. Different to exit polls, this way also nonvoters could be included in the dataset. To incentivize participation, students were invited to take part in a lottery of 250 euros and 15 times 2 tickets for a local cinema. The survey was open from July 6 till November 11, 2010.

The tracks and stations covered by the train tickets are depicted in Figure 1. Before 2010, there had been one train ticket covering, with only minor changes, all tracks depicted, served by several operators. The vote in 2010, however, was preceded by complaints from students' representatives about the price which Deutsche Bahn charged for its part of the tracks. As a result, the ticket was split in two. The first one covered the offer by two companies named Metronom and Cantus, henceforth called MetroCan ticket (tracks drawn as solid red lines in Figure 1), and was approved in January 2010. The second one covered the tracks served by Deutsche Bahn and two smaller companies (drawn as dashed lines in blue in Figure 1). The latter companies are jointly referred to as Bahn throughout this paper. After some negotiations with Bahn, a referendum on the Bahn ticket was held in May 2010. Information in Dataset II refers to this referendum. In later years, including 2013, the ticket proposal again covered all tracks.

\subsection{Dataset I}

After dropping students who did not provide any voting decision, Dataset I contains 1334 observations. Summary statistics are shown in Table 1. Within our sample, the shares of yes votes for all three tickets are slightly higher than the respective overall shares. Students in the dataset would have just passed the bus ticket which narrowly missed the $50 \%$ approval threshold in the referendum. However, as our sample contains detailed information on one seventh of all votes cast, we are confident that these deviations are of minor importance when analyzing individual voting decisions. 
Figure 1: Map

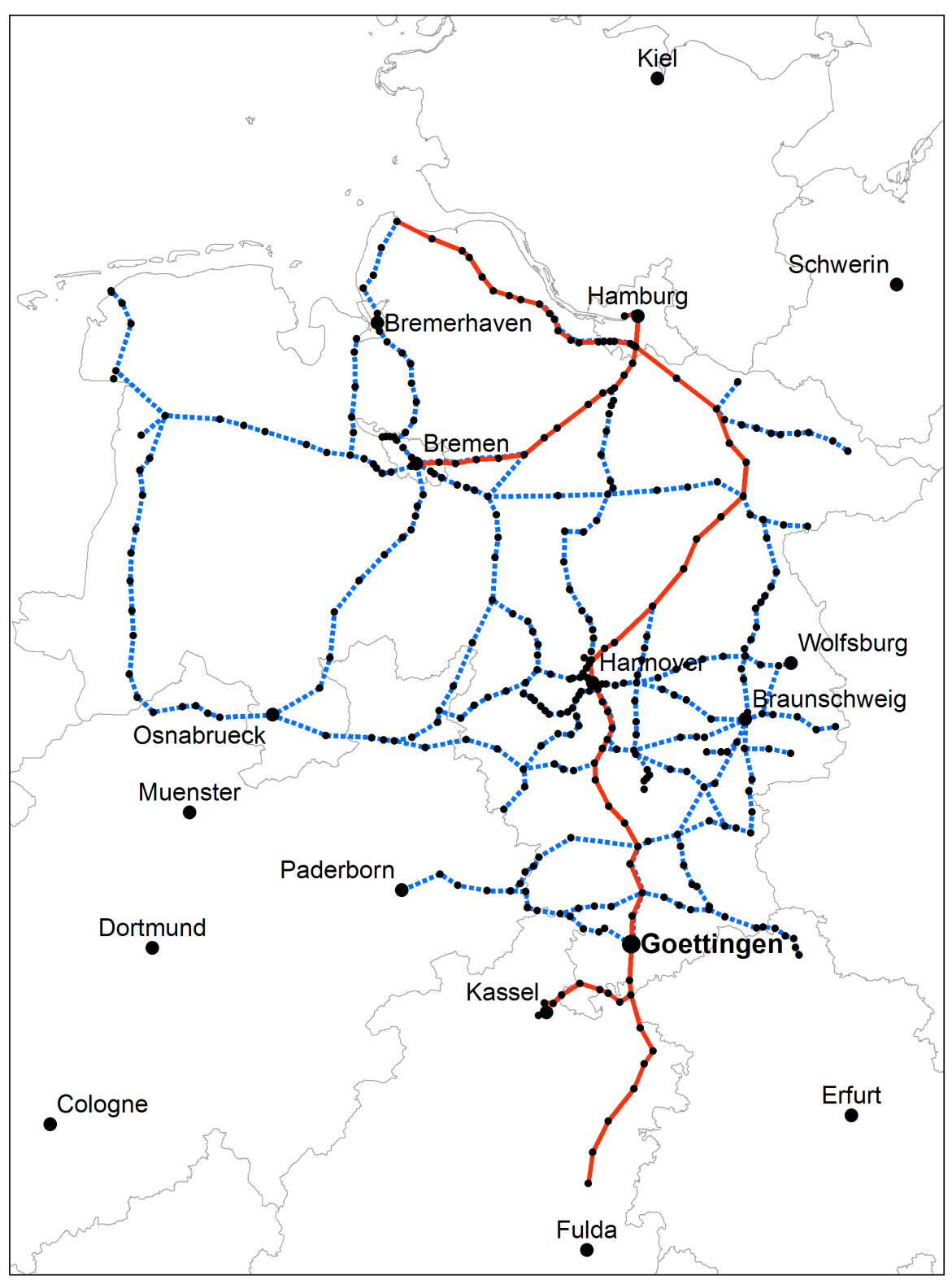

The tracks covered by the Bahn (dashed blue lines) and MetroCan (solid red lines) tickets. Grey lines are state boundaries. 
Table 1: Summary statistics - Dataset I

\begin{tabular}{|c|c|c|}
\hline Variable & $\mathrm{N}$ & Mean \\
\hline \multicolumn{3}{|l|}{ Train ticket } \\
\hline Train ticket: yes & 1252 & 0.86 \\
\hline Would buy it & 1248 & 0.64 \\
\hline Never & 1321 & 0.07 \\
\hline Rarely $(\leq 5 /$ year $)$ & 1321 & 0.17 \\
\hline Sometimes (monthly) & 1321 & 0.32 \\
\hline Often (weekly) & 1321 & 0.21 \\
\hline Very often $(\geq 2 /$ week $)$ & 1321 & 0.24 \\
\hline Savings of others important & 1292 & 0.47 \\
\hline Environment important & 1284 & 0.38 \\
\hline \multicolumn{3}{|l|}{ Bus ticket $\diamond$} \\
\hline Bus ticket: yes & 1246 & 0.51 \\
\hline Would buy it & 1276 & 0.37 \\
\hline Never & 1329 & 0.40 \\
\hline Rarely ( 1 or 2 /semester) & 1329 & 0.24 \\
\hline Sometimes (monthly) & 1329 & 0.13 \\
\hline Often (weekly) & 1329 & 0.09 \\
\hline Very often $(\geq 2 /$ week $)$ & 1329 & 0.14 \\
\hline Savings of others important & 1280 & 0.23 \\
\hline Strengthening bus important & 1245 & 0.12 \\
\hline \multicolumn{3}{|l|}{ Cult ure ticket } \\
\hline Culture ticket: yes & 1283 & 0.54 \\
\hline Would buy it & 1233 & 0.44 \\
\hline Never & 1234 & 0.56 \\
\hline Rarely ( 1 or $2 /$ year) & 1234 & 0.25 \\
\hline Sometimes ( 3 to $5 /$ year) & 1234 & 0.12 \\
\hline Often ( 6 to $10 /$ year) & 1234 & 0.04 \\
\hline Very often $(>10 /$ year $)$ & 1234 & 0.03 \\
\hline Savings of others important & 1235 & 0.24 \\
\hline Others should go important & 1201 & 0.29 \\
\hline Strengthening local culture important & 1229 & 0.39 \\
\hline \multicolumn{3}{|l|}{ Control variables } \\
\hline Female & 1276 & 0.50 \\
\hline Freshman & 1318 & 0.30 \\
\hline Christian Democrats & 1140 & 0.26 \\
\hline Social Democrats & 1140 & 0.29 \\
\hline Liberal Democrats & 1140 & 0.04 \\
\hline Green & 1140 & 0.31 \\
\hline Left & 1140 & 0.05 \\
\hline Other parties & 1140 & 0.05 \\
\hline Economic sciences & 1322 & 0.30 \\
\hline Social sciences & 1322 & 0.24 \\
\hline Forestry/Agriculture & 1322 & 0.06 \\
\hline Humanities & 1322 & 0.27 \\
\hline Geology/Geography & 1322 & 0.03 \\
\hline Law & 1322 & 0.11 \\
\hline Natural sciences & 1322 & 0.08 \\
\hline Other fields & 1322 & 0.03 \\
\hline
\end{tabular}

$\diamond$ Intensity of the use of the bus ticket refers to lecture period. 
The intensity of use is measured by categorical variables defined differently for the tickets (see Table 1). For the train and culture tickets, students were asked about their use within the last 12 months and the year before the ticket had been introduced, respectively. For the bus ticket, the intensity of use refers to teaching periods during term. Since first-year students had not been at the university for a full year, we control for freshman status in the regression analysis.

For each of the three tickets the survey contains a question capturing whether the respondent considered savings of other students important for his or her vote. Answers to these questions were given on a four point Likert scale ranging from 'not important' to 'important'. Furthermore, we asked about other motives, like environmental aspects in the case of the train ticket or strengthening local transportation or local cultural life, using the same Likert scale. In Table 1, we give the shares of students who replied that the respective consideration was important. Additional control variables are gender and fields of study. ${ }^{1}$ Moreover, political preferences were captured by a question on how the respondent would vote in a federal election if this were to take place the following Sunday. Finally, students were asked if they would buy the ticket for themselves in case the ticket would be rejected in the referendum but would be available to be bought for the same price on individual basis.

\subsection{Dataset II}

Summary statistics for Dataset II are reported in Table 2. This dataset consists of 1189 observations after cleaning the data. ${ }^{2}$ Out of these, 828 students took part in the referendum. This shows an overrepresentation of voters in our sample. At the same time, it allows us to base our analysis on detailed information of almost one sixth of all voters of the referendum. Among the voters in the sample, the share of yes votes is $68 \%$, and hence smaller than the share of yes votes in the polling box.

The key variable in this dataset is the individual savings of each student. We construct an objective measure of the savings associated with the Bahn ticket by combining the number of trips to the respondents' parents using this ticket within the last 12 months with the price that would have to be paid in absence of the ticket. $^{3}$ We focus on trips to parents as these are the most common trips students make. Moreover, the two bigger cities close to Goettingen, namely Hannover and Kassel, which might be attractive leisure destinations, can be reached using the MetroCan ticket (see Figure 1). For the analysis of the decision to take part in the

\footnotetext{
${ }^{1}$ Due to the high number of polling stations the survey team could not cover all during opening hours on all three days. Therefore the faculties of Law, Humanities, Economic sciences and Social sciences are over-represented in the dataset.

${ }^{2}$ See Appendix A.I for a detailed description.

${ }^{3} \mathrm{~A}$ detailed description of the calculation of savings is included as Appendix A.II.
} 
Table 2: Summary statistics - Dataset II

\begin{tabular}{|c|c|c|c|c|}
\hline \multirow[b]{2}{*}{ Variable } & \multicolumn{2}{|c|}{ All } & \multicolumn{2}{|c|}{ Vote on Bahn ticket $=1$} \\
\hline & $\mathrm{N}$ & Mean & $\mathrm{N}$ & Mean \\
\hline Vote on Bahn ticket & 1189 & 0.70 & 828 & 1.00 \\
\hline Bahn ticket: yes & 818 & 0.68 & 818 & 0.68 \\
\hline Savings $\diamond$ & 1189 & 255.09 & 828 & 302.92 \\
\hline Stakes $\boldsymbol{\phi}$ & 1189 & 259.31 & 828 & 297.56 \\
\hline Own price threshold & 1125 & 69.76 & 783 & 72.31 \\
\hline Exp. ave. price threshold ${ }^{\curvearrowright}$ & 1099 & 63.20 & 764 & 63.03 \\
\hline Leisure/work & 1189 & 0.06 & 828 & 0.06 \\
\hline Visiting others & 1174 & 0.65 & 819 & 0.67 \\
\hline Female & 1176 & 0.57 & 817 & 0.54 \\
\hline Freshman & 1099 & 0.15 & 768 & 0.18 \\
\hline Altruist $(-)$ & 1074 & 0.14 & 741 & 0.13 \\
\hline Altruist $(+)$ & 1074 & 0.34 & 741 & 0.33 \\
\hline Protest & 1189 & 0.21 & 828 & 0.24 \\
\hline
\end{tabular}

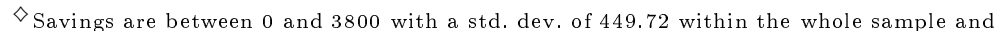
487.99 among the voters, $\$$ stakes are between 0 and 3715.52 with a std. dev. of 405.06 and 444.15 respectively, ${ }^{*}$ own price thresholds are between 0 and 750 with a std. dev. of 65.22 and 64.14 respectively, expected average price thresholds are between 10 and 720 with a std. dev. of 47.92 and 46.76 respectively.

referendum, we transform the savings variable by subtracting the ticket price per year and taking the absolute value. Thereby, we gain a quantitative measure of the stakes a student has in the referendum.

Control variables in this dataset include gender and the party the student voted for in the last federal election in 2009 (not reported in Table 2 for brevity). Further variables contain information on whether or not the student visited people other than his or her parents using the ticket and whether the student is a freshman. This is relevant since first-year students in the dataset started university in October 2009 only. Thus, they could not use the ticket for a full year.

The questionnaire also allowed students to enter free text on the main reasons to vote in favor or against the Bahn ticket. In order to use this qualitative information, a content analysis was done to identify relevant topics. Afterwards, three raters independently coded all answers with respect to whether a topic did apply. Finally, an indicator variable, that is equal to one if at least two out of the three raters independently identified the topic in the statement given and zero otherwise, was defined.

We use two variables resulting from this qualitative analysis: leisure/work captures if the student mentioned leisure activities other than visiting people, such as exploring the region or work related aspects. The second item emerging from the content analysis is protest: some students expressed their unwillingness to accept the price of the ticket or were afraid that acceptance of the conditions would 
foster future price increases. Among the voters, the share of students referring to leisure/work and protest is about $6 \%$ and $24 \%$, respectively.

Dataset II includes information on the highest prices at which students would vote in favor of the Bahn ticket and their beliefs about the corresponding average of fellow students. We also asked students how they weighted these two amounts in their vote. If the decision was not only influenced by his or her own amount, a student is classified as altruist. The resulting group of altruists is then split into those who think that students on average gain from this ticket, and those who think that students on average lose. Accordingly, altruist $(+)$ is equal to one if the student based his or her decision not only on his or her own amount and believes that the price threshold of fellow students is on average greater than the price, and zero otherwise. We define altruist(-) analogously. If the student did not vote, these two indicator variables are based on the hypothetical question how he or she would have weighted these amounts.

\section{The big picture}

In this section, we take a closer look at the data in a descriptive analysis. The big picture that emerges is that there is strong evidence for pocketbook voting, but that social preferences also play an important role. For a first impression of the relevance of pocketbook voting, consider Figure 2. This figure depicts the share of yes votes in Dataset I depending on how intensively the voter used the service on which the vote took place. There is a strong link between own use and the likelihood of voting yes. For each ticket, more than $90 \%$ of those who used the service very often voted in favor, while the share of yes votes varies between $24 \%$ and $32 \%$ for those who never used the service.

To understand to what extent pocketbook considerations can explain voting, we relate the voting decision to the binary variable stating whether the respondent would have bought the ticket individually in case it would be rejected in the referendum. If voting followed exclusively pocketbook considerations, we would expect those who vote in favor to be willing to buy the ticket also if this was available for an individual purchase, and those who vote against to be unwilling to do so. Table 3 shows that $93 \%$ to $96 \%$ of those who voted against a semester ticket would also decline an opportunity to buy it privately. Remarkably, $23 \%$ to $27 \%$ of those who voted in favor of a ticket would not be willing to buy it privately for the same price. Taken together, about 30\% of respondents voted differently as a citizen compared with the choice that they would make as a private consumer. We conjecture that social preferences explain most of this difference.

To test our conjecture, we next counted which fraction of those who voted in 
Figure 2: Intensity of use and yes votes - Dataset I

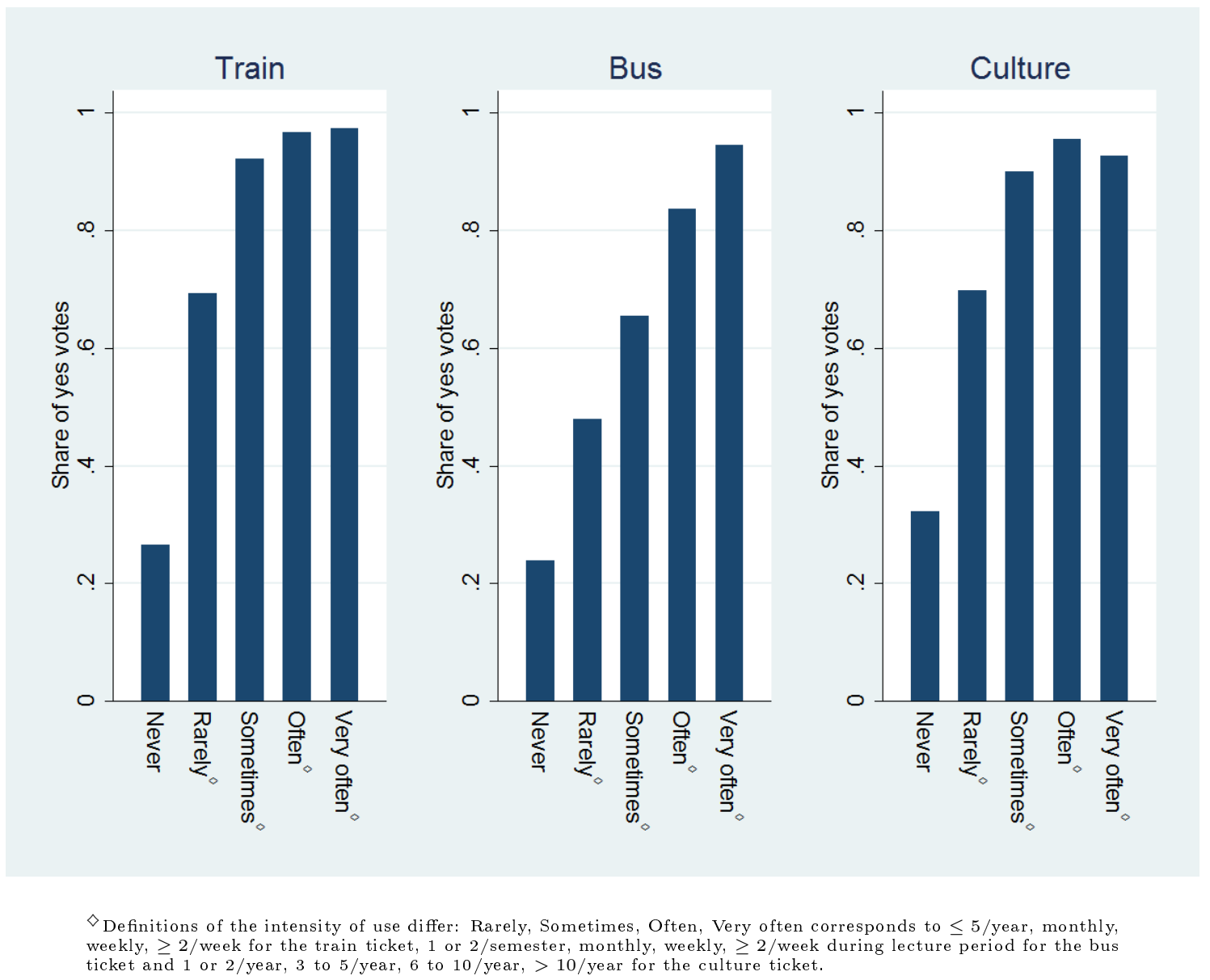

favor of each ticket but would not buy it privately reported that at least one social motive was important (strong social preferences), and which fraction reported that none was important but at least one was somewhat important (moderate social preferences). The social preferences we consider relate to altruistic concerns towards other students when a respondent mentions that savings of others are a motivation to vote in favor of a ticket, or to a common good, when a respondent supports the service in question because it is good for the environment (in case of the train ticket) or because he or she wants to strengthen the local culture or the bus system. Social preferences also encompass responses that other students should use cultural services more often.

Table 4 shows that strong social preferences were especially pronounced among those supporting the culture ticket even if not being willing to buy it privately. 
Table 3: Pocketbook voting - Dataset I

\begin{tabular}{c|cc|c}
\hline \hline \multicolumn{4}{|c}{ Train ticket } \\
\hline \multirow{2}{*}{ Buy it } & \multicolumn{2}{|c}{ Vote } & \multirow{2}{*}{ Total } \\
& No & Yes & \\
\hline No & 158 & 256 & 414 \\
Yes & 11 & 755 & 766 \\
\hline Total & 169 & 1,011 & 1,180 \\
\hline \hline
\end{tabular}

\begin{tabular}{c|cc|c}
\hline \hline \multicolumn{4}{|c}{ Bus ticket } \\
\hline \multirow{2}{*}{ Buy it } & \multicolumn{2}{|c}{ Vote } & \multirow{2}{*}{ Total } \\
& No & Yes & \\
\hline No & 572 & 160 & 732 \\
Yes & 21 & 441 & 462 \\
\hline Total & 593 & 601 & 1,194 \\
\hline \hline
\end{tabular}

\begin{tabular}{c|cc|c}
\hline \hline \multicolumn{4}{c}{ Culture ticket } \\
\hline \multirow{2}{*}{ Buy it } & \multicolumn{2}{|c}{ Vote } & \multirow{2}{*}{ Total } \\
& No & Yes & \\
\hline No & 519 & 147 & 666 \\
Yes & 27 & 495 & 522 \\
\hline Total & 546 & 642 & 1,188 \\
\hline \hline
\end{tabular}

Table 4: Voting in favor but unwilling to buy: importance of social preferences

\begin{tabular}{lccc}
\hline \hline & Train & Bus & Culture \\
\hline Strong social preferences & 137 & 75 & 99 \\
Moderate social preferences & 92 & 69 & 46 \\
No social preferences & 21 & 10 & 0 \\
\hline Total & 250 & 154 & 145 \\
\hline \hline & \\
Strong social preferences: at least one social motive was im- \\
portant for the student. Moderate social preferences: at least \\
one social motives was somewhat important for the student \\
but no motive was important. No social preferences: all social \\
motives were unimportant for the student. Social motives con- \\
sidered include for all three tickets savings of other students. \\
They also include environmental aspects for the train ticket, \\
strengthening local public transportation for the bus ticket, \\
and strengthening local cultural life and the belief that oth- \\
ers should visit cultural institutions more frequently for the \\
culture ticket.
\end{tabular}

In fact, everyone who supported the culture ticket without being willing to buy it claimed at least moderate social preferences. More than $90 \%$ of those voting in favor of train or bus ticket in spite of not being willing to buy it privately reported at least moderate social preferences.

Figure 3 summarizes these findings. It shows that $77 \%$ to $85 \%$ of all votes can be rationalized by pocketbook voting, corresponding to voting in favor of a ticket in case one would buy it privately at the price charged and voting against in case one would not buy it. Almost all votes which cannot be rationalized in this way can be rationalized by social preferences. Only one to two percent of respondents voted against a ticket, despite having own pocketbook consideration to support the service. The share of unrationalizable yes votes, those supporting a service which they would not demand privately at the quoted price, and for which they did not express any social concerns, varies between zero and two percent.

When interpreting Figure 3, it is important to note that own financial interests and social preferences are not mutually exclusive, but may coincide. Therefore, the figure does not state that $80 \%$ of all voters would base their decision just on their own financial benefit. Rather, it shows that there are very few votes which cannot be rationalized by either pocketbook voting or social considerations or both kinds of 
Figure 3: Rationalizing votes - Dataset I

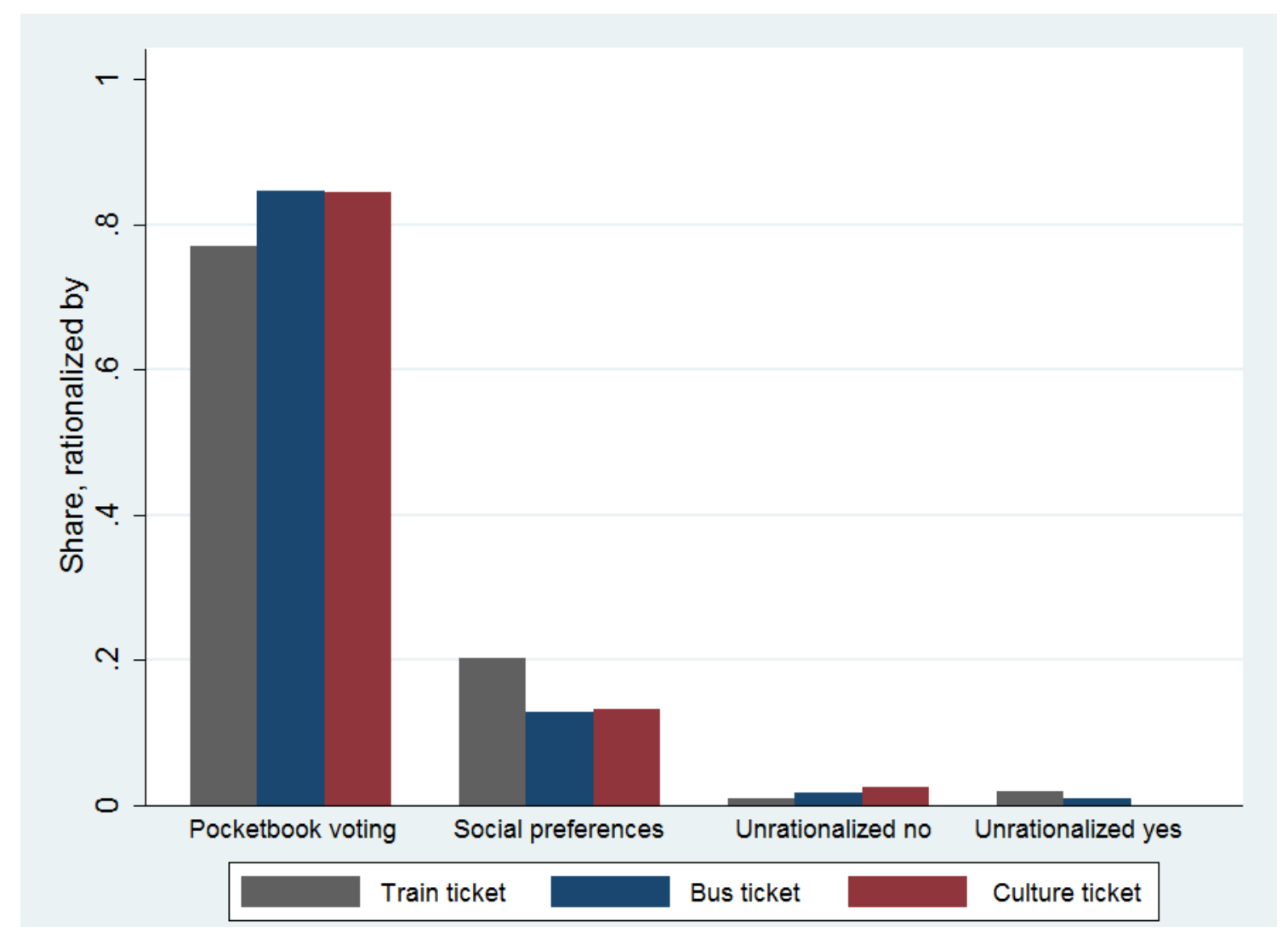

motivation together. We have done the analysis summarized in Figure 3 splitting the sample by gender and by political orientation. We find that the differences between men and women and between supporters of the left and of the right are minor.

To see the full power of social preferences, note from Table 3 that although only a minority of students in the sample would have bought the culture ticket or the bus ticket, a majority supported them in the referenda. As Figure 3 shows, for a sizable minority of voters, social preferences were the decisive factor shifting their decision. Given that results in the actual referenda on culture and bus ticket were close, this suggests that social preferences were pivotal in the former vote and came close to being pivotal in the latter.

For each ticket, Table 5 goes deeper into various social preferences of those who voted in favor of the ticket but would not buy it privately. For train and bus, altruistic consideration for savings by others is by far the most important social motivation to support the ticket. Four out of five also view environmental benefits as an at least somewhat important motivation to support the train ticket. A collective 
Table 5: Voting in favor but unwilling to buy: different social preferences

\begin{tabular}{lccc|c}
\hline \hline & Important & Somewhat important & Unimportant & Total \\
\hline $\begin{array}{l}\text { Train ticket } \\
\text { Savings of others } \\
\text { Environment }\end{array}$ & 119 & 106 & 29 & 254 \\
$\begin{array}{l}\text { Bus ticket } \\
\text { Savings of others }\end{array}$ & 96 & 105 & 50 & 251 \\
$\begin{array}{l}\text { Strengthening bus system } \\
\text { Culture ticket }\end{array}$ & 63 & 70 & 24 & 157 \\
$\begin{array}{l}\text { Savings of others } \\
\text { Strengthening local culture }\end{array}$ & 54 & 69 & 57 & 155 \\
Others should go & 65 & 65 & 26 & 145 \\
\hline \hline
\end{tabular}

purchase decision in favor of an environmentally friendlier form of transportation can be seen as a way to avoid free-riding in protecting the environment.

For the culture ticket, a different picture arises. The most common motivation to support this ticket as a voter, even if not being willing to buy it as consumer, is strengthening local cultural institutions. This motivation, in turn, can have an altruistic component, but also be self-interested: a stronger local cultural landscape improves the choices one has available as private consumer. Altruistic motivation by savings of others and the view that others should attend cultural activities more often are less pronounced. Interestingly, the latter motivation appears to be somewhat more common than concern for the savings of others. Wanting other students to consume more culture can be interpreted as paternalism, but might also reflect a desire to have more company at cultural events.

Yet another reason for supporting the culture ticket could be related to problems of self-control. Students possibly want to commit themselves to consume more culture, just as a flat rate gym membership can be seen as a commitment device to exercise more (DellaVigna and Malmendier, 2006). Note however that buying such a ticket privately would provide a commitment device too. The fact that a substantial number of respondents voting in favor of the ticket would not do this but at the same time state that others should attend cultural events more often suggests that many students see the self-control problem rather in their fellow students than in themselves.

We now turn to Dataset II which refers to the vote in 2010 on the Bahn ticket. First, we note that savings on the trips to parents are highly diverse. While almost half of the students do not use the Bahn ticket at all for visiting their parents, mean savings amount to 255 euros. Figure 4 depicts the share of yes votes according to the magnitude of the savings conferred by this ticket for trips to students' parents. About $40 \%$ in the lowest four deciles, which consist of students with zero savings, 
Figure 4: Savings and share of yes votes - Dataset II

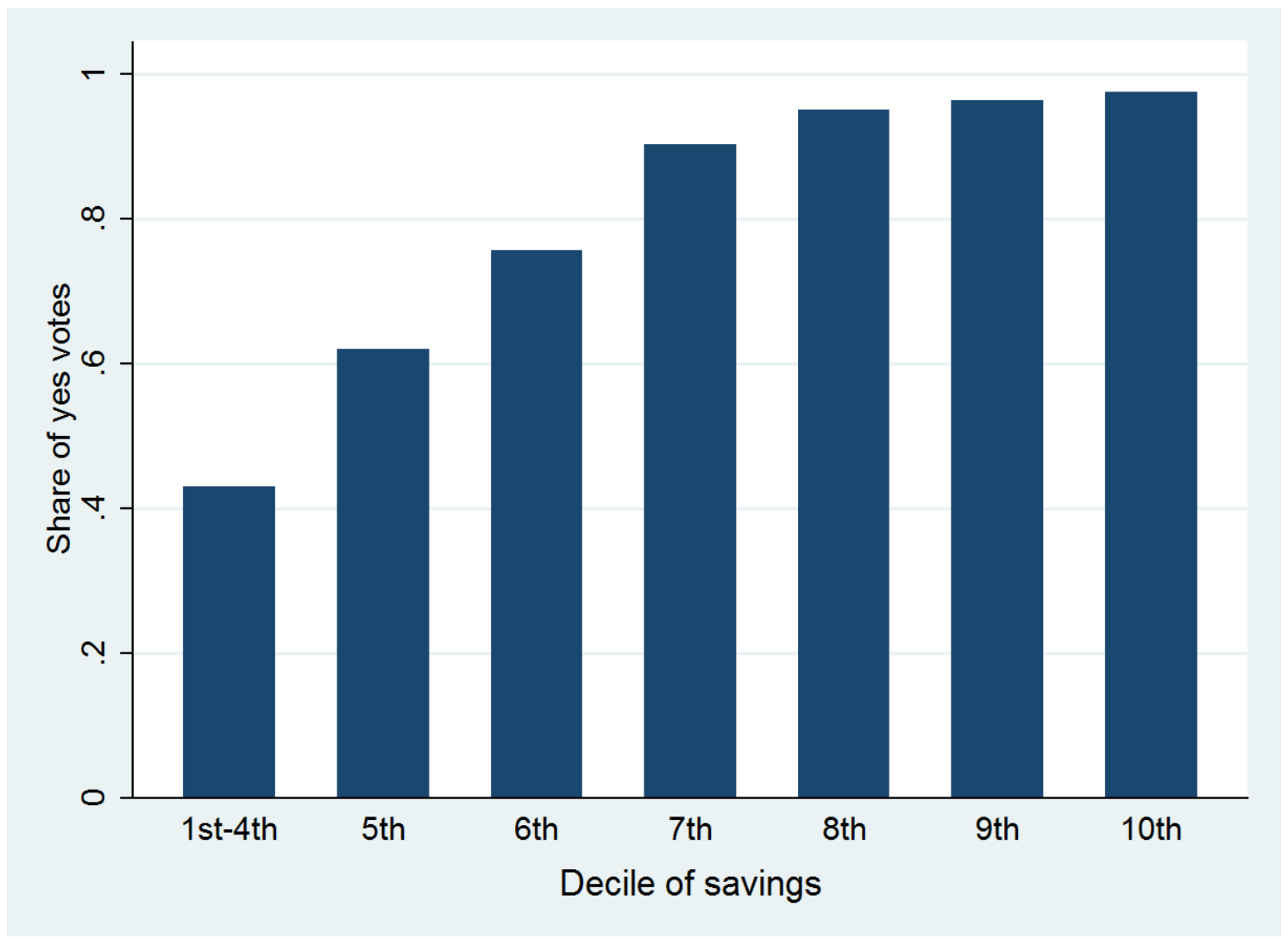

voted in favor of the ticket. Thereafter, support for the ticket increased monotonically when moving to higher savings deciles, exceeding $90 \%$ for the four highest deciles. Therefore, the picture we find is again very much in line with pocketbook voting.

We also asked students whether they used the ticket for other visits than those to their parents. This allows us to define those for whom savings from visiting parents were less than the price of the ticket and who did neither visit other people using the ticket nor mentioned leisure or work related trips as losers in terms of private benefits, and those for whom the savings from visiting parents exceeded the price of the ticket as clear winners. Those for whom savings from visiting parents fell short from the price of the ticket but who also mentioned other trips are a middle category, in which we cannot say for sure whether the student in question privately gained or lost from the ticket. Table 6 shows that $92 \%$ of winners voted in favor of the ticket, and $75 \%$ of losers against. Therefore, pocketbook voting can again rationalize most of the votes, but there is also a significant minority that voted against their narrowly 
Table 6: Pocketbook voting - Dataset II

\begin{tabular}{c|cc|c}
\hline \hline \multicolumn{3}{c|}{ Bahn ticket } & \multirow{2}{*}{ Vote } \\
\hline \multirow{2}{*}{ Net gain } & No & Yes & Total \\
\hline Loser & 144 & 49 & 193 \\
Moderate savings \& add. monetary gains & 80 & 140 & 220 \\
Winner & 34 & 368 & 402 \\
\hline Total & 258 & 557 & 815 \\
\hline \hline & \\
Losers' savings do not cover ticket costs and they did neither visit other \\
people using the ticket nor mention leisure/work activities. Savings of \\
the middle group alone do not cover ticket costs, but they mention other \\
trips. Winners' savings cover ticket costs.
\end{tabular}

Table 7: Social preferences and protest among winners and losers - Dataset II

\begin{tabular}{c|cc|c}
\hline \hline \multicolumn{4}{c}{ Bahn ticket, only losers } \\
\hline \multirow{2}{*}{ Altruist $(+)$} & \multicolumn{2}{c}{ Vote } & Total \\
& No & Yes & \\
\hline No & 119 & 17 & 136 \\
Yes & 12 & 23 & 35 \\
\hline Total & 131 & 40 & 171 \\
\hline \hline
\end{tabular}

\begin{tabular}{|c|c|c|c|}
\hline \multicolumn{4}{|c|}{ Bahn ticket, only winners } \\
\hline \multirow{2}{*}{ Altruist $(-)$ or protest } & \multicolumn{2}{|c|}{ Vote } & \multirow{2}{*}{ Total } \\
\hline & No & Yes & \\
\hline No & 9 & 239 & 248 \\
\hline Yes & 23 & 100 & 123 \\
\hline Total & 32 & 339 & 371 \\
\hline
\end{tabular}

Losers' savings do not cover ticket costs and they did neither visit other people using the ticket nor mention leisure/work activities. Winners' savings cover ticket costs.

defined self-interest.

Looking closer at those who voted against their narrowly defined self-interest shows that most respondents who lost privately but voted in favor of the ticket cared about the savings that the ticket delivered to other students. To analyze such concerns, we use the variables altruist $(+)$ and altruist $(-)$ which describe students who stated that they cared about other students' benefits in their vote and at the same time thought that students on average gain or lose, respectively, when the ticket is introduced. As can be seen in Table 7, the majority of respondents who voted in favor of the ticket even if they lost privately thought that other students gained from it and reported that they cared about this. Among those who voted against the ticket, even if it promised them higher private savings than the price of the ticket, a clear majority was either of the view that other students would lose from the ticket, or mentioned protest motives regarding price or pricing policy in the questionnaire's write-in section.

We also analyzed how the decision to participate in the vote was related to the savings when visiting parents. Figure 5 presents turnout separately for those who lost, for those with moderate savings for whom we cannot say whether other trips than those to visiting parents were enough to make them gain from the ticket 
Figure 5: Turnout and savings- Dataset II

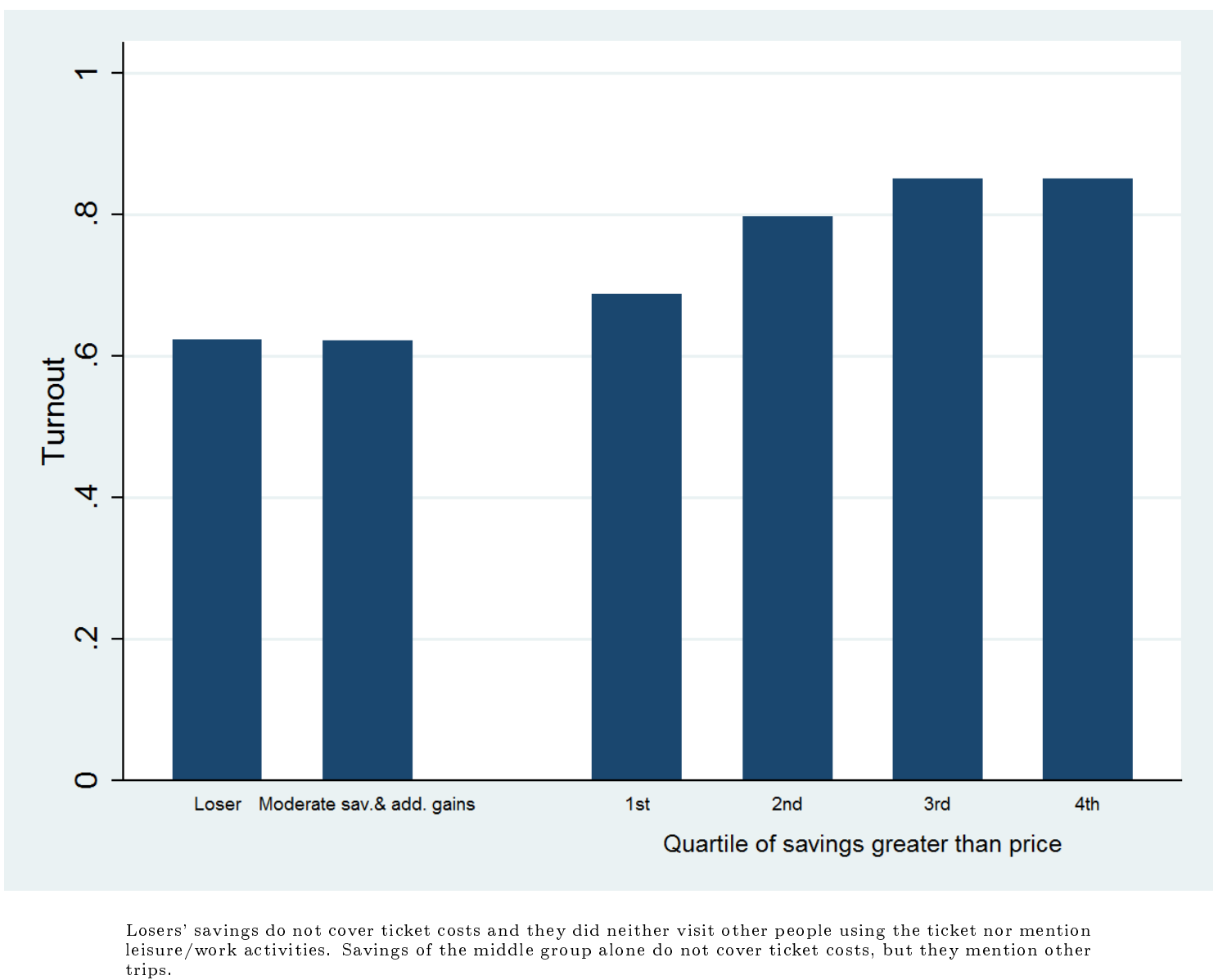

privately, as well as for those whose savings when visiting parents were bigger than the price. Those with zero and moderate savings are least likely to turn out. After that, turnout increases monotonically. This suggests that those with higher stakes are more likely to vote, in line with rational calculus of voting. It is worth noting that gains and losses are asymmetrically distributed: the maximum loss is the price of ticket (84.48 euros), while the average saving just from visiting parents is among the winners 586 euros.

Taken together, our findings suggest that voters voted on the collective purchasing decisions largely in line with their financial interests. At the same time, social preferences also shaped voting decisions. In particular, there is a considerable altruistic component, and many students explicitly referred to the benefits for other students in the write-in section. A big share of students were also motivated to 
support public good provision, possibly as a way of solving the free-rider problem in case of private choices: as a result, they supported a collective purchasing decision even at a price for which they would not have been willing to buy the ticket privately. In the area of culture, a paternalistic component is also important, with a large fraction of students being willing to support the culture ticket as a nudge to push other students to use cultural services more often. Differences in turnout decision are in line with what rational calculus of voting suggests: those who have more to gain are more likely to vote.

\section{The vote}

We now turn to the regression analysis of the voting decisions. The dependent variable is the probability to vote in favor of the respective ticket which we estimate using probit models. We start with the first dataset and present results for the train, bus and culture ticket in Tables 8 to 10. Indicator variables for social preferences take the value one if the respondent considered the respective motivation important; descriptive statistics are given in Table 1. In order to interpret the results right away, we display marginal effects ${ }^{4}$ for benchmark students in the regression tables. These students are characterized by all indicator variables being zero. Thus, the benchmark is male, not a freshman and savings of other students were not important for his decision. The base category of the intensity of use is "never".

Our econometric results confirm the impressions gained in Section 3: the probability of voting in favor of a ticket strongly increases in the intensity of personal use, suggesting a high degree of pocketbook voting. The effects are significant at the 0.1 percent-level and of economically relevant size. For instance, concerning the bus ticket estimations imply that an otherwise identical student who uses the bus several times per week is more than 70 percentage-points more likely to vote in favor of this ticket than the benchmark student who does not use the bus.

However, variables capturing social preferences show highly significant and positive effects too. Those who consider savings of other students important for their decision vote in favor of the respective ticket with higher probability. Also, students who consider environmental aspects or strengthening of local public transportation important are more likely to vote in favor of the train ticket or the bus ticket, respectively. The same holds true regarding the culture ticket for those who indicate that strengthening local cultural life or that others should visit these institutions more frequently is important to them in their voting decision. ${ }^{5}$

\footnotetext{
${ }^{4}$ We calculate marginal effects as discrete changes from zero to one for all indicator variables. Coefficients for all regressions are reported in tables A.1-A.6 in Appendix A.III.

${ }^{5} \mathrm{~A}$ very similar picture emerges from the regression analysis if we use indicator variables encom-
} 
Table 8: Train ticket - Dataset I

\begin{tabular}{|c|c|c|c|c|}
\hline \multicolumn{5}{|c|}{ Dependent Variable: Supporting Train Ticket } \\
\hline & $(1)$ & $(2)$ & $(3)$ & $(4)$ \\
\hline Rarely $(\leq 5 /$ year $)$ & $\begin{array}{c}0.428^{* * *} \\
(7.35)\end{array}$ & $\begin{array}{c}0.422^{* * *} \\
(7.41)\end{array}$ & $\begin{array}{c}0.393^{* * *} \\
(6.73)\end{array}$ & $\begin{array}{c}0.373^{* * *} \\
(6.21)\end{array}$ \\
\hline Sometimes (monthly) & $\begin{array}{c}0.657 * * * \\
(13.05)\end{array}$ & $\begin{array}{c}0.683^{* * *} \\
(14.23)\end{array}$ & $\begin{array}{c}0.680 * * * \\
(13.56)\end{array}$ & $\begin{array}{c}0.676^{* * *} \\
(13.14)\end{array}$ \\
\hline Often (weekly) & $\begin{array}{c}0.701^{* * * *} \\
(14.10)\end{array}$ & $\begin{array}{c}0.750^{* * *} \\
(15.65)\end{array}$ & $\begin{array}{c}0.749 * * * \\
(14.61)\end{array}$ & $\begin{array}{c}0.745^{* * *} \\
(14.19)\end{array}$ \\
\hline Very often $(\geq 2 /$ week $)$ & $\begin{array}{c}0.709 * * * \\
(14.39)\end{array}$ & $\begin{array}{c}0.764 * * * \\
(16.26)\end{array}$ & $\begin{array}{c}0.766^{* * *} \\
(15.19)\end{array}$ & $\begin{array}{c}0.760 * * * \\
(14.69)\end{array}$ \\
\hline Savings of others & & $\begin{array}{c}0.300^{* * *} \\
(6.11)\end{array}$ & $\begin{array}{c}0.285^{* * * *} \\
(5.48)\end{array}$ & $\begin{array}{c}0.198^{* * *} \\
(3.65)\end{array}$ \\
\hline Female & & & $\begin{array}{c}0.090^{*} \\
(2.44)\end{array}$ & $\begin{array}{c}0.074^{*} \\
(2.04)\end{array}$ \\
\hline Freshman & & & $\begin{array}{l}-0.043 \\
(-1.39)\end{array}$ & $\begin{array}{l}-0.029 \\
(-0.92)\end{array}$ \\
\hline Environment & & & & $\begin{array}{c}0.242^{* *} \\
(3.25)\end{array}$ \\
\hline Pseudo $\mathrm{R}^{2}$ & 0.285 & 0.334 & 0.342 & 0.364 \\
\hline Log Likelihood & -356.2 & -315.2 & -298.1 & -277.9 \\
\hline Observations & 1247 & 1217 & 1163 & 1145 \\
\hline
\end{tabular}

Probit estimation, discrete effects for benchmark students from changes from 0 to 1 for all variables, $\mathrm{z}$-statistic in parentheses. ${ }^{*} p<0.05,{ }^{* *} p<0.01,{ }^{* * *} p<0.001$.

Freshmen are, ceteris paribus, more likely to vote in favor of the bus ticket and the culture ticket. However, as for freshmen the questions on the intensity of use refer to a shorter period of time or might cover some time when they have not yet been in Goettingen, we refrain from emphasizing this finding.

To examine whether general political attitudes contribute to explaining individual votes, we include party preferences in the regressions. Even though the parties traditionally present in German parliaments cannot easily be ordered in a strict way from the left to the right, there arguably exists the general consensus that Social Democrats and the Greens represent the center left and that the Left Party is positioned according to its name. Liberal Democrats and Christian Democrats form the center right.

As is apparent from Table A.7 in Appendix A.IV, the strong empirical support for both pocketbook voting and social considerations is robust to the inclusion of party preferences. Furthermore, for neither bus nor train ticket do we find significant

passing motives that were at least somewhat important instead of focusing on motives that were important. In line with expectations, these variables capturing less pronounced social preferences in general display smaller marginal effects than those shown in Tables 8-10. We have also included complete sets of indicator variables containing information on whether someone considered a motive unimportant, somewhat important, or important, and the conclusions remained the same. (Not reported for brevity.) 
Table 9: Bus ticket - Dataset I

\begin{tabular}{lcccc}
\hline \multicolumn{4}{c}{ Dependent Variable: Supporting Bus Ticket } \\
\hline Rarely (1 or 2/semester) & $0.241^{* * *}$ & $0.218^{* * *}$ & $0.217^{* * *}$ & $0.203^{* * *}$ \\
& $(6.94)$ & $(6.31)$ & $(6.15)$ & $(5.64)$ \\
Sometimes (monthly) & $0.415^{* * *}$ & $0.398^{* * *}$ & $0.416^{* * *}$ & $0.411^{* * *}$ \\
& $(9.81)$ & $(8.88)$ & $(8.79)$ & $(8.19)$ \\
Often (weekly) & $0.597^{* * *}$ & $0.597^{* * *}$ & $0.617^{* * *}$ & $0.587^{* * *}$ \\
& $(14.88)$ & $(13.63)$ & $(13.58)$ & $(11.38)$ \\
Very often ( $\geq 2 /$ week) & $0.706^{* * *}$ & $0.726^{* * *}$ & $0.744^{* * *}$ & $0.728^{* * *}$ \\
& $(27.55)$ & $(25.34)$ & $(24.39)$ & $(20.17)$ \\
Savings of others & & $0.221^{* * *}$ & $0.204^{* * *}$ & $0.158^{* * *}$ \\
Female & & $(5.93)$ & $(5.36)$ & $(4.07)$ \\
& & & -0.006 & 0.007 \\
Freshman & & $(-0.27)$ & $(0.29)$ \\
Strengthening bus system & & $0.081^{* *}$ & $0.067^{*}$ \\
& & & $(2.92)$ & $(2.44)$ \\
\hline Pseudo R & & & $0.418^{* * *}$ \\
Log Likelihood & 0.224 & 0.245 & 0.252 & 0.285 \\
Observations & -668.1 & -623.5 & -589.1 & -539.1 \\
\hline \hline
\end{tabular}

Probit estimation, discrete effects for benchmark students from changes from 0 to 1 for all variables, $\mathrm{z}$-statistic in parentheses. ${ }^{*} p<0.05,{ }^{* *} p<0.01,{ }^{* * *} p<0.001$.

Table 10: Culture ticket - Dataset I

\begin{tabular}{|c|c|c|c|c|}
\hline \multicolumn{5}{|c|}{ Dependent Variable: Supporting Culture Ticket } \\
\hline & (1) & $(2)$ & $(3)$ & $(4)$ \\
\hline Rarely (1 or $2 /$ year) & $\begin{array}{c}0.376^{* * *} \\
(11.67)\end{array}$ & $\begin{array}{c}0.347^{* * *} \\
(9.91)\end{array}$ & $\begin{array}{c}0.355^{* * *} \\
(9.60)\end{array}$ & $\begin{array}{c}0.290^{* * * *} \\
(6.83)\end{array}$ \\
\hline Sometimes (3 to $5 /$ year) & $\begin{array}{c}0.578^{* * * *} \\
(18.57)\end{array}$ & $\begin{array}{c}0.570^{* * * *} \\
(15.26)\end{array}$ & $\begin{array}{c}0.597^{* * * *} \\
(13.28)\end{array}$ & $\begin{array}{c}0.572^{* * * *} \\
(7.80)\end{array}$ \\
\hline Often (6 to $10 /$ year) & $\begin{array}{c}0.634^{* * * *} \\
(17.78)\end{array}$ & $\begin{array}{c}0.643^{* * *} \\
(14.19)\end{array}$ & $\begin{array}{c}0.693^{* * * *} \\
(12.09)\end{array}$ & $\begin{array}{c}0.649^{* * *} \\
(4.94)\end{array}$ \\
\hline Very often $(>10 /$ year $)$ & $\begin{array}{c}0.605^{* * *} \\
(13.59)\end{array}$ & $\begin{array}{c}0.585^{* * *} \\
(9.37)\end{array}$ & $\begin{array}{c}0.640^{* * *} \\
(7.96)\end{array}$ & $\begin{array}{c}0.522^{* *} \\
(2.95)\end{array}$ \\
\hline Savings of others & & $\begin{array}{c}0.280^{* * *} \\
(6.91)\end{array}$ & $\begin{array}{c}0.262^{* * *} \\
(6.21)\end{array}$ & $\begin{array}{l}0.104^{*} \\
(2.40)\end{array}$ \\
\hline Female & & & $\begin{array}{c}0.071^{*} \\
(2.53)\end{array}$ & $\begin{array}{l}0.019 \\
(0.80)\end{array}$ \\
\hline Freshman & & & $\begin{array}{c}0.109^{* *} \\
(3.17)\end{array}$ & $\begin{array}{c}0.084^{*} \\
(2.58)\end{array}$ \\
\hline Others should go & & & & $\begin{array}{c}0.433^{* * *} \\
(5.83)\end{array}$ \\
\hline Strengthening local culture & & & & $\begin{array}{c}0.453^{* * * *} \\
(8.74) \\
\end{array}$ \\
\hline Pseudo $\mathrm{R}^{2}$ & 0.192 & 0.215 & 0.215 & 0.440 \\
\hline Log Likelihood & -664.7 & -599.2 & -571.1 & -378.7 \\
\hline Observations & 1189 & 1110 & 1055 & 988 \\
\hline
\end{tabular}

Probit estimation, discrete effects for benchmark students from changes from 0 to 1 for all variables, z-statistic in parentheses. ${ }^{*} p<0.05,{ }^{* *} p<0.01,{ }^{* * *} p<0.001$. 
effects for any of the parties. ${ }^{6}$ Thus, party politics in general is not driving the voting decisions here. However, political attitudes seem to play a role when it comes to the joint provision of local cultural goods. Even within the left bloc our results show differences with respect to voting behavior. Namely, we find that support for the culture ticket, ceteris paribus, increases as party preferences become more leftist.

As a robustness check, we also control for the fields of study (Table A.8 in Appendix A.IV). The overall picture is that they do not seem to matter much for individual votes. Only a small number of fields show significant effects on the voting decisions and our main results remain robust. All else being equal, students of the humanities and social sciences are more likely to vote in favor of the culture ticket. One explanation for this can be based on the large share of students in these fields that study culture-related subjects. Our main findings are also robust to the inclusion of both fields and party preferences into the regressions (Table A.9 in Appendix A.IV).

Turning to our second dataset and the constructed measure of monetary savings, a very similar picture emerges. In order to account for the expected non-linear effect of savings on the decision we use the natural logarithm of savings, after adding 1 euro, in the regressions. Table 11 shows corresponding marginal effects for benchmark students. Again, the benchmark is defined by all indicator variables being zero. However, to account for the high variation with respect to individual savings on trips to parents, we incorporate the individual values of the savings variable also in the calculation of marginal effects. Hence, we display average marginal effects for benchmark students.

The main variable of interest, the natural logarithm of savings on trips to parents, is significant at the 0.1 percent-level and shows the expected positive sign. The corresponding marginal effect does virtually not change if we include additional variables. It implies that a benchmark student is on average 0.7-0.8 percentage points more likely to vote in favor if savings increase by $10 \%$. Given the range of the variable, this translates into sizeable differences in the prediction: Based on the full specification, column (5), the probability of a positive vote is $14 \%$ for a benchmark student who does not save at all on trips to parents. This value increases to $56 \%$ if his savings just cover ticket costs, which is remarkably close to our expectations based on theoretical considerations; such a student should be fairly indifferent between the alternatives. The predicted probability is $67 \%$ if his savings are of average size and $79 \%$ if he saved a thousand euros. In addition, visiting others using the ticket significantly increases the probability of voting in favor. This confirms the high importance of personal monetary benefits for the individual vote.

However, social preferences have their share in this vote too: both altruism

\footnotetext{
${ }^{6}$ Results are similar if we group parties to the left bloc and the right bloc.
} 
Table 11: Bahn ticket - Dataset II

\begin{tabular}{|c|c|c|c|c|c|}
\hline \multicolumn{6}{|c|}{ Dependent Variable: Supporting Bahn Ticket } \\
\hline & (1) & $(2)$ & (3) & (4) & $(5)$ \\
\hline Log savings & $\begin{array}{c}0.070^{* * *} \\
(24.47)\end{array}$ & $\begin{array}{c}0.070^{* * *} \\
(17.90)\end{array}$ & $\begin{array}{c}0.073^{* * *} \\
(18.36)\end{array}$ & $\begin{array}{c}0.077^{* * *} \\
(22.52)\end{array}$ & $\begin{array}{c}0.078^{* * *} \\
(24.48)\end{array}$ \\
\hline Leisure/work & & $\begin{array}{l}0.079 \\
(1.02)\end{array}$ & $\begin{array}{l}0.033 \\
(0.41)\end{array}$ & $\begin{array}{c}0.042 \\
(0.52)\end{array}$ & $\begin{array}{l}0.046 \\
(0.56)\end{array}$ \\
\hline Visiting others & & $\begin{array}{c}0.296^{* * *} \\
(8.31)\end{array}$ & $\begin{array}{c}0.308^{* * *} \\
(8.22)\end{array}$ & $\begin{array}{c}0.269^{* * *} \\
(6.50)\end{array}$ & $\begin{array}{c}0.272^{* * *} \\
(6.62)\end{array}$ \\
\hline Female & & & $\begin{array}{l}0.055 \\
(1.51)\end{array}$ & $\begin{array}{c}0.043 \\
(1.13)\end{array}$ & $\begin{array}{c}0.042 \\
(1.09)\end{array}$ \\
\hline Freshman & & & $\begin{array}{c}0.103^{*} \\
(2.04)\end{array}$ & $\begin{array}{c}0.127^{*} \\
(2.42)\end{array}$ & $\begin{array}{c}0.134^{*} \\
(2.57)\end{array}$ \\
\hline Altruist(-) & & & & $\begin{array}{c}-0.149^{* *} \\
(-3.04)\end{array}$ & $\begin{array}{c}-0.147^{* *} \\
(-2.94)\end{array}$ \\
\hline Altruist(+) & & & & $\begin{array}{c}0.288^{* * *} \\
(6.78)\end{array}$ & $\begin{array}{c}0.286^{* * *} \\
(6.83)\end{array}$ \\
\hline Protest & & & & & $\begin{array}{l}-0.080 \\
(-1.93) \\
\end{array}$ \\
\hline Pseudo $\mathrm{R}^{2}$ & 0.225 & 0.306 & 0.333 & 0.434 & 0.438 \\
\hline Log Likelihood & -395.7 & -351.7 & -307.4 & -236.0 & -234.2 \\
\hline Observations & 818 & 810 & 741 & 669 & 669 \\
\hline
\end{tabular}

Probit estimation, marginal effects for benchmark students, discrete changes from 0 to 1 for indicator variables, z-statistic in parentheses. ${ }^{*} p<0.05,{ }^{* *} p<0.01,{ }^{* * *} p<0.001$

variables carry the expected sign and are significant at least at the 1 percent-level. About half of the students consider their fellow students' gains and losses in their vote. According to their own perception of whether the other students on average gain or lose, these students are, ceteris paribus, more or less likely, respectively, than the benchmark to vote in favor of the ticket. Expecting other students to gain from the ticket and considering this, increases support for the ticket as much as using it oneself to also visit other people than one's parents. Furthermore, the protest variable carries a negative sign and is almost significant at the 5 percent-level. So, there is weak evidence suggesting that some students expressed their protest against the train company's pricing policy by voting against the ticket.

Finally, as in the analysis of Dataset I, including general political preferences in the regressions does not change our results. All else being equal, supporters of the left are not more likely to vote in favor of the ticket. This holds true for individual parties as well as for grouping of the left and right into blocs. ${ }^{7}$

Without putting too much emphasis on this, it is noted that especially private savings and the altruism variables contribute to the pseudo R-squared in Table 11.

A general concern related to survey data is how reliable answers are. In our setting, this problem may arise in particular when it comes to social preferences because

\footnotetext{
${ }^{7}$ Results are available upon request.
} 
of social desirability. For example, one might wonder whether respondents genuinely care for others or just feel social pressure to express such a concern. However, both the descriptive and econometric analyses show that stated social preferences, in particular altruism, have a substantial impact on the voting decision, explaining most votes which cannot be rationalized by monetary benefits.

From an econometric perspective, one might be concerned with reverse causality, omitted variables or sample selection. A reverse causality problem would arise if those respondents who voted in favor of a ticket against their monetary interest ex post rationalized their decision by mentioning social preferences. However, this argumentation leaves open the question of why they voted in favor of the ticket in the first place. Given the extensive set of controls we use, there is no obvious candidate for an omitted variable which affects the voting decision and is correlated with the explanatory variables. An issue of sample selection could arise if respondents in the surveys systematically differed from the student population. As shown in Section 2, voters are somewhat overrepresented in Dataset II. This is, however, not a problem since we excluded nonvoters from the analysis of voting decisions. Finally, semester tickets should only play a minor role when deciding whether to enroll at Goettingen University. Taken together, we do not think that any of these issues is likely to seriously bias our results.

Summarizing our empirical analysis so far, we find, first, that pocketbook voting is an important determinant of referendum outcomes, second, that party politics plays only a minor role and, third, that monetary self-interest is not the whole story. In particular, social preferences should not be disregarded. Especially so, as the descriptive analysis in Section 3 suggested that these motives were or came close to being pivotal in two out of four referenda studied.

\section{Participation}

We now turn to the second part of our analysis, which is to understand what induced students to turn out in the referendum. For this purpose, we use Dataset II which also contains detailed information on non-voters.

Specifically, we investigate whether the calculated savings are also able to explain participation in the referendum. Hence, we estimate the probability of taking part in the vote conditional on the explanatory variables using probit specifications. As described above, we therefore transform savings into stakes, defined as the absolute value of the difference of the yearly price and savings. In the regressions, we use the natural logarithm of these stakes augmented by one euro. Table 12 shows average 
marginal effects for benchmark students. ${ }^{8}$ Looking at the full sample, regressions (1)-(4), we see a highly significant positive effect of stakes. This effect is robust to the inclusion of additional control variables. It seems that students whose stakes are high make sure to take part in the referendum.

Table 12: Taking part - Dataset II

\begin{tabular}{lcccccc}
\hline \hline \multicolumn{7}{c}{ Dependent Variable: Taking } \\
\hline & $(1)$ & $(2)$ & $(3)$ & $(4)$ & $(5)$ & \\
& all & all & all & all & savings $\geq$ price & savings $<$ price \\
\hline Log stakes & $0.070^{* * *}$ & $0.072^{* * *}$ & $0.074^{* * *}$ & $0.077^{* * *}$ & $0.046^{* *}$ & 0.041 \\
& $(5.94)$ & $(5.85)$ & $(5.88)$ & $(6.00)$ & $(2.99)$ & $(1.04)$ \\
Leisure/work & & -0.017 & -0.007 & -0.008 & -0.014 & -0.003 \\
& & $(-0.28)$ & $(-0.12)$ & $(-0.14)$ & $(-0.16)$ & $(-0.03)$ \\
Visiting others & & 0.041 & 0.033 & 0.031 & 0.036 & -0.009 \\
& & $(1.46)$ & $(1.17)$ & $(1.09)$ & $(0.73)$ & $(-0.22)$ \\
Female & & & $-0.106^{* * *}$ & $-0.107^{* * *}$ & $-0.124^{* *}$ & $-0.087^{*}$ \\
& & & $(-3.61)$ & $(-3.58)$ & $(-2.61)$ & $(-2.16)$ \\
Freshman & & & $0.137^{* * *}$ & $0.140^{* * *}$ & 0.081 & $0.188^{* * *}$ \\
& & & $(4.29)$ & $(4.18)$ & $(1.85)$ & $(3.95)$ \\
Protest & & & & $0.087^{* *}$ & 0.061 & $0.094^{*}$ \\
& & & & $(2.81)$ & $(1.51)$ & $(2.09)$ \\
\hline Pseudo R ${ }^{2}$ & 0.023 & 0.026 & 0.050 & 0.056 & 0.046 & 0.027 \\
Log Likelihood & -713.1 & -700.8 & -625.6 & -622.0 & -213.2 & -403.5 \\
Observations & 1189 & 1174 & 1075 & 1075 & 449 & 626 \\
\hline \hline
\end{tabular}

Probit estimation, marginal effects for benchmark students, discrete changes from 0 to 1 for indicator variables, z-statistic in parentheses. Regression (5): only students whose savings cover ticket costs (winners), regression (6): only students whose savings do not cover ticket costs. ${ }^{*} p<0.05,{ }^{* *} p<0.01,{ }^{* * *} p<0.001$

Unlike for the decision to vote in favor or against, visiting others does not have a significant effect on the decision to take part. Being female reduces the probability of voting, whereas being freshman increases it. However, we cannot disentangle alternative possible explanations driving the freshman effect. It could be based on the fact that savings of freshmen refer to a shorter period of time, or alternatively, it may reflect that many freshmen are enthusiastic to use the first chance to take part in such a referendum. Students who mention protest motives go to the polls with a significantly higher probability.

Splitting the sample into those whose savings on trips to parents cover ticket costs and those whose savings do not, we find that stakes remain significant among the winners at the 1 percent-level, but turn insignificant among the second group. This may be due to the asymmetric distribution of gains and losses: the latter are limited to the yearly price of the ticket, 84.48 euros, whereas stakes of someone who uses the Bahn ticket every weekend to visit his or her parents can be much higher.

\footnotetext{
${ }^{8}$ As in Section 4 all indicator variables are zero for benchmark students. The continuous variable, $\log$ of stakes plus 1 euro, enters calculations of marginal effects at individual values.
} 
Table 13: Taking part, reduced sample - Dataset II

\begin{tabular}{lcccccc}
\hline \hline \multicolumn{7}{c}{ Dependent Variable: Taking Part in Referendum } \\
\hline \multirow{2}{*}{ Bottom } & $(1)$ & $(2)$ & $(3)$ & $(4)$ & $(5)$ & $(6)$ \\
\hline Log stakes & $95 \%$ & $90 \%$ & $85 \%$ & $80 \%$ & $75 \%$ & $70 \%$ \\
\hline Leisure/work & $0.082^{* * *}$ & $0.073^{* * *}$ & $0.068^{* * *}$ & $0.052^{*}$ & 0.029 & 0.011 \\
& $(5.32)$ & $(4.21)$ & $(3.41)$ & $(2.23)$ & $(1.09)$ & $(0.39)$ \\
Visiting others & -0.006 & -0.012 & -0.022 & -0.011 & -0.005 & -0.028 \\
& $(-0.10)$ & $(-0.17)$ & $(-0.31)$ & $(-0.15)$ & $(-0.07)$ & $(-0.35)$ \\
Female & 0.037 & 0.038 & 0.043 & 0.037 & 0.023 & 0.007 \\
& $(1.26)$ & $(1.25)$ & $(1.35)$ & $(1.11)$ & $(0.67)$ & $(0.19)$ \\
Freshman & $-0.106^{* * *}$ & $-0.106^{* *}$ & $-0.102^{* *}$ & $-0.094^{* *}$ & $-0.097^{* *}$ & $-0.081^{*}$ \\
& $(-3.39)$ & $(-3.27)$ & $(-3.07)$ & $(-2.72)$ & $(-2.74)$ & $(-2.22)$ \\
Protest & $0.150^{* * *}$ & $0.153^{* * *}$ & $0.148^{* * *}$ & $0.162^{* * *}$ & $0.160^{* * *}$ & $0.157^{* * *}$ \\
& $(4.15)$ & $(4.08)$ & $(3.71)$ & $(3.86)$ & $(3.63)$ & $(3.39)$ \\
& $0.098^{* *}$ & $0.100^{* *}$ & $0.098^{* *}$ & $0.099^{* *}$ & $0.109^{* *}$ & $0.105^{* *}$ \\
Pseudo R & $(3.01)$ & $(3.00)$ & $(2.76)$ & $(2.67)$ & $(2.88)$ & $(2.69)$ \\
Log Likelyhood & 0.052 & 0.044 & 0.036 & 0.030 & 0.027 & 0.022 \\
Observations & -594.8 & -580.7 & -558.1 & -535.0 & -509.4 & -486.7 \\
\hline \hline
\end{tabular}

Probit estimation, marginal effects for benchmark students, discrete changes from 0 to 1 for indicator variables, z-statistic in parentheses. Columns show percentiles with respect to stakes, e.g. column (1) contains those observations who belong to the bottom $95 \%$ with respect to stakes. ${ }^{*} p<0.05,{ }^{* *} p<0.01,{ }^{* * *} p<0.001$.

Remarkably, those who mention protest motives take part in the referendum with significantly higher probability only among those whose savings fall short of the ticket price. One potential interpretation for this result could be that for someone who gains monetarily from the ticket, protest and monetary interest are opposing motives. Contrary to that, in the case of smaller savings, both motives should shift the vote in the direction of rejection of the ticket. Therefore, the latter group might have a stronger opinion concerning rejection or approval, which could foster participation.

In order to further examine the question whether high gains drive our results here, we gradually remove observations with the highest stakes from the dataset. Table 13 contains corresponding average marginal effects for benchmark students. In regression (1), we only leave out the top $5 \%$ students in terms of stakes, whereas in regression (6), we only use the bottom $70 \%$. Stakes have a positive and highly significant effect if we use almost all observations. The more we remove observations with high stakes, the smaller the size and z-statistic of the marginal effect become. Looking at the bottom $75 \%$ only, the effect is not significantly different from zero anymore. In contrast, the significance of the control variables female, freshman and protest suffers much less from this reduction of the sample, and the marginal effects are much more stable. This suggests that the loss of significance of the stakes variable should not be attributed to the smaller sample size alone. 
Reverse causality should not be a problem in the analysis of the participation decision. Variables capturing travel patterns and demographics are clearly not affected by the decision to vote. The protest variable is derived from the write-in section, so that it seems unlikely that it captures ex-post rationalization of participation decision. In contrast, stated altruism could be affected by the participation decision. In fact, non-voters more often claim that they would have considered the benefit of others, had they voted, than voters do. One interpretation for this is that, given that one did not take an actual decision, it is easy to claim noble motivations. For this reason, we did not include the altruism variables in the regressions explaining the participation decision.

Sample selection and omitted variables are a more serious concern given the underrepresentation of non-voters in the sample. If the decisions to vote and to take part in the survey are affected by the same unobserved variable, our participation regressions could be biased. However, it is not clear what such a variable could be and in which direction it would bias our results.

Summing up, the results from this section shed some light on the motives to turn out in referenda. First, we find that students who mention protest motives take part with a higher probability, suggesting expressive voting. Second, our results are also in line with the theory of instrumental voting which predicts that for a given probability of being pivotal and given costs of voting, participation should increase in stakes. More specifically, we conclude that especially those who gain a lot, and hence, lose a lot if the ticket fails, drive this result. Thus, in a referendum, one may expect a disproportionately higher turnout by voters who stand to benefit substantially when the proposal passes, whereas voters who are affected only moderately are more likely to abstain.

\section{Conclusion}

In this paper, we investigate determinants of individual votes in four referenda on deep-discount flat rate tickets on train, bus and cultural services held among students. Introducing such a ticket resembles the collective provision of a public good. The service becomes much cheaper by providing it collectively, but all voters, including those who do not use the service, have to pay taxes to finance it.

Our results show that monetary interests are a major driver of both turnout and voting decisions. However, we also find that in addition to this 'pocketbook voting', altruistic and social motives such as the costs and benefits of other students or a desire to support local public transportation or cultural life are also important, and occasionally even decisive for the referendum outcome. Finally, we found evidence for some students taking part in the referendum in order to express dissatisfaction 
with the train company's pricing policy. Remarkably, among those upset by the high price of the ticket, those who would lose from the ticket being introduced were more likely to turn out to express their protest.

The set of referenda we study concerns a relatively small group of voters and has the specific feature that voters had very good information on individual costs and benefits of the decision on the ballot. While this allows to study voting motives in a clearly defined setting, it remains an open question to study to what extent our results carry over to referenda in a broader context. In particular, we expect ideology and general political attitudes to play a larger role when it comes to referenda on much bigger issues. Nevertheless, similarly to laboratory experiments, it seems plausible that the major voting motives we identify in the present study will also be active in other direct democratic decisions. 


\section{Appendix}

\section{A.I Data handling}

The survey for Dataset II was conducted online between July and November 2010. It was advertised in lectures, on posters on campus and in two e-mails that were sent to all students of Goettingen University from the office of student affairs. On the survey webpage students were informed that the survey was conducted for research purposes and about a possibility to participate in a lottery. At the end of the questionnaire, students were provided with a link to another webpage, where they could register for the lottery. In order to identify winners without ambiguity, we required the (unique) student ID number for a registration for the lottery as well as an e-mail address. For the sake of data protection, questionnaire data and lottery data were collected in separate databases. As the savings variable plays a key role in explaining the decision on whether to vote and if voting, then how to vote, we excluded observations without information on voting behavior or for which we cannot assess savings, because, for instance, we lack data on traveling behavior or the corresponding student started studying only one month before the referendum took place. Besides, we removed less than fifteen observations from the dataset due to clear data errors or where answers given seemed highly implausible, such as visiting parents 20,000 times in one year.

A challenge in the data management is that 75 ID numbers show up twice and on different days, suggesting that 75 students also show up twice in the dataset. Using the time stamps of the lottery data showed that in most cases, the responses were entered shortly after receiving an e-mail from the office of student affairs that was advertising the survey. Therefore, it is likely that these students had forgot that they had already answered a survey or thought that they should answer for a second time. After we explored this issue, we realized that we also have time stamps for survey responses, although in a separate data base. To guarantee the anonymity of respondents, we recruited a research assistant who was not otherwise connected to the project to select those entries from the lottery data that belong to duplicates in the lottery data base and to provide the two timestamps for each of the 75 pairs. As only timestamps were extracted pairwisely from the lottery database, anonymity was guaranteed at all times. Specifically, no individual information that could be used to identify the person behind a timestamp, such as a student ID number, was extracted from the lottery data.

Timestamps from the lottery were then assigned to the time stamps in the response dataset. For all pairs of time stamps, we examined responses that were submitted close to the time stamp in the lottery. For all pairs of these subsamples, 
we identified potential pairs of observations present in both subsamples, based on the data provided. Initial selection was made using gender, year of birth and the zip code of their parents. If students indicated that their parents do not live together, the maternal, or if missing the paternal, zip code was used. If these three variables, year of birth, gender and parental zip code, were the same for observations in both subsamples, they were considered potential duplicates based on the data provided. Potential duplicates were then compared based on additional variables, such as subjects studied, travel frequencies, general attitudes and voting decisions, party preferences and reasons to be in favor and against the ticket. This procedure allowed us to identify 46 pairs of assigned duplicates. Consequently, we dropped the later entry of every pair of duplicates from the dataset. This left us with 29 pairs of duplicates which we could not identify. This corresponds to about two percent of the dataset and should, therefore, have only a tiny effect on the results. To be on the safe side, we also replicated the analysis of the second dataset without excluding observations based on this assignment. The results remain virtually unchanged.

\section{A.II Construction of the savings variable}

In the survey, students were asked about their parents' address and how many times they visited their parents' residence within the last 12 months (July 1, 2009 - June 30, 2010) using the Bahn ticket. If students indicated that their parents did not live in the same city, questions were asked for both parents separately.

To translate trips to parents into monetary savings, the nearest train station covered by the Bahn ticket was identified for every parental address (zip code) using a standard route planner. ${ }^{9}$ Afterwards, for each station, the relevant price was derived. Therefore, we identified the suggested route to Goettingen using local trains for all stations on the Bahn tracks (dashed blue lines on the map, Figure 1) using software provided by Deutsche Bahn. At the time of the referendum, it was already known that students could use the MetroCan tracks (solid red lines) without additional costs. Consequently, savings per trip from the Bahn ticket are the price that would have to be paid to the station on this route where the "free" train (red) is entered. ${ }^{10}$

If the determined price was greater than 21 euros it was capped to this amount to reflect the possibility to buy the so called Lower-Saxony-ticket that is valid on all local trains in the state on the day of validation at this price. As furthermore every

\footnotetext{
${ }^{9}$ Google maps, standard proposal for cars.

${ }^{10}$ Due to the non-linear pricing in the German railway market, this price is in most cases not equal to the price from a station to Goettingen less the price from the station where the free train is entered to Goettingen.
} 
visit consists of the way back and forth, final savings are calculated as the product of the relevant price and twice the number of visits using the Bahn ticket. To also reflect the opportunity to buy a train ticket for all trains in Germany including high speed trains (BahnCard100) at a price of 3800 euros per year at the time of the survey, the savings variable is capped at 3800 euros.

For some students in Dataset II, Goettingen is not the nearest train station. Most of these students live in the same town as their parents, presumably with their parents. For these students, the savings variable captures direct monetary savings when they come to campus. If they live apart from their parents we calculate savings correspondingly, starting from their respective nearest station. Ten students, however, live outside Goettingen apart from their parents and save little on trips to them, but could primarily use this ticket for commuting. We refrain from calculating savings in these cases as they might severely misrepresent the benefit from the ticket. Consequently, these observations are dropped. 


\section{A.III Coefficients}

Table A.1: Train ticket - Dataset I, coefficients for Table 8

\begin{tabular}{|c|c|c|c|c|}
\hline \multicolumn{5}{|c|}{ Dependent Variable: Supporting Train Ticket } \\
\hline & $(1)$ & $(2)$ & $(3)$ & $(4)$ \\
\hline Rarely $(\leq 5 /$ year $)$ & $\begin{array}{c}1.131^{* * *} \\
(0.17)\end{array}$ & $\begin{array}{c}1.164^{* * *} \\
(0.19)\end{array}$ & $\begin{array}{c}1.099^{* * *} \\
(0.19)\end{array}$ & $\begin{array}{c}1.060^{* * *} \\
(0.20)\end{array}$ \\
\hline Sometimes (monthly) & $\begin{array}{c}2.047^{* * *} \\
(0.18)\end{array}$ & $\begin{array}{c}2.018^{* * *} \\
(0.19)\end{array}$ & $\begin{array}{c}1.997^{* * *} \\
(0.20)\end{array}$ & $\begin{array}{c}1.976^{* * * *} \\
(0.21)\end{array}$ \\
\hline Often (weekly) & $\begin{array}{c}2.452^{* * *} \\
(0.21)\end{array}$ & $\begin{array}{c}2.423^{* * *} * \\
(0.22)\end{array}$ & $\begin{array}{c}2.386^{* * *} \\
(0.23)\end{array}$ & $\begin{array}{c}2.334^{* * *} \\
(0.24)\end{array}$ \\
\hline Very often $(\geq 2 /$ week $)$ & $\begin{array}{l}2.574^{* * * *} \\
(0.21)\end{array}$ & $\begin{array}{l}2.555^{* * *} \\
(0.23)\end{array}$ & $\begin{array}{l}2.528^{* * * *} \\
(0.24)\end{array}$ & $\begin{array}{c}2.439^{* * *} \\
(0.24)\end{array}$ \\
\hline Savings of others & & $\begin{array}{c}0.855^{* * *} \\
(0.13)\end{array}$ & $\begin{array}{c}0.826^{* * *} \\
(0.13)\end{array}$ & $\begin{array}{c}0.613^{* * *} \\
(0.15)\end{array}$ \\
\hline Female & & & $\begin{array}{c}0.301^{* *} \\
(0.12)\end{array}$ & $\begin{array}{c}0.260^{*} \\
(0.12)\end{array}$ \\
\hline Freshman & & & $\begin{array}{l}-0.179 \\
(0.12)\end{array}$ & $\begin{array}{r}-0.122 \\
(0.13)\end{array}$ \\
\hline Environment & & & & $\begin{array}{c}0.730^{* * *} \\
(0.18)\end{array}$ \\
\hline Constant & $\begin{array}{c}-0.628^{* * *} \\
(0.15) \\
\end{array}$ & $\begin{array}{c}-0.883^{* * *} \\
(0.17)\end{array}$ & $\begin{array}{c}-0.912^{* * *} \\
(0.19)\end{array}$ & $\begin{array}{c}-0.947^{* * *} \\
(0.20)\end{array}$ \\
\hline Pseudo $\mathrm{R}^{2}$ & 0.285 & 0.334 & 0.342 & 0.364 \\
\hline Log Likelihood & -356.2 & -315.2 & -298.1 & -277.9 \\
\hline Observations & 1247 & 1217 & 1163 & 1145 \\
\hline
\end{tabular}


Table A.2: Bus ticket - Dataset I, coefficients for Table 9

\begin{tabular}{|c|c|c|c|c|}
\hline \multicolumn{5}{|c|}{ Dependent Variable: Supporting Bus Ticket } \\
\hline & $(1)$ & $(2)$ & $(3)$ & $(4)$ \\
\hline Rarely ( 1 or $2 /$ semester) & $\begin{array}{c}0.659^{* * *} \\
(0.10)\end{array}$ & $\begin{array}{c}0.630^{* * *} \\
(0.10)\end{array}$ & $\begin{array}{c}0.654^{* * *} \\
(0.10)\end{array}$ & $\begin{array}{c}0.631^{* * *} \\
(0.11)\end{array}$ \\
\hline Sometimes (monthly) & $\begin{array}{c}1.106^{* * *} \\
(0.12)\end{array}$ & $\begin{array}{c}1.086^{* * *} \\
(0.12)\end{array}$ & $\begin{array}{c}1.159^{* * *} \\
(0.13)\end{array}$ & $\begin{array}{c}1.160^{* * *} \\
(0.14)\end{array}$ \\
\hline Often (weekly) & $\begin{array}{c}1.690^{* * *} \\
(0.16)\end{array}$ & $\begin{array}{c}1.674^{* * *} \\
(0.16)\end{array}$ & $\begin{array}{c}1.746^{* * *} \\
(0.16)\end{array}$ & $\begin{array}{c}1.653^{* * *} \\
(0.17)\end{array}$ \\
\hline Very often $(\geq 2 /$ week $)$ & $\begin{array}{c}2.306^{* * *} \\
(0.16)\end{array}$ & $\begin{array}{c}2.305^{* * * *} \\
(0.17)\end{array}$ & $\begin{array}{c}2.350^{* * *} \\
(0.18)\end{array}$ & $\begin{array}{c}2.222^{* * *} \\
(0.19)\end{array}$ \\
\hline Savings of others & & $\begin{array}{c}0.637^{* * * *} \\
(0.10)\end{array}$ & $\begin{array}{c}0.621^{* * *} \\
(0.10)\end{array}$ & $\begin{array}{c}0.509 * * * \\
(0.11)\end{array}$ \\
\hline Female & & & $\begin{array}{r}-0.023 \\
(0.09)\end{array}$ & $\begin{array}{l}0.026 \\
(0.09)\end{array}$ \\
\hline Freshman & & & $\begin{array}{c}0.273^{* *} \\
(0.09)\end{array}$ & $\begin{array}{c}0.238^{*} \\
(0.09)\end{array}$ \\
\hline Strengthening bus system & & & & $\begin{array}{c}1.179^{* * *} \\
(0.18)\end{array}$ \\
\hline Constant & $\begin{array}{c}-0.710^{* * *} \\
(0.06) \\
\end{array}$ & $\begin{array}{c}-0.826 * * * \\
(0.07) \\
\end{array}$ & $\begin{array}{c}-0.915^{* * *} \\
(0.09) \\
\end{array}$ & $\begin{array}{c}-0.959 * * * \\
(0.09)\end{array}$ \\
\hline Pseudo $\mathrm{R}^{2}$ & 0.224 & 0.245 & 0.252 & 0.285 \\
\hline Log Likelihood & -668.1 & -623.5 & -589.1 & -539.1 \\
\hline Observations & 1242 & 1192 & 1137 & 1090 \\
\hline
\end{tabular}


Table A.3: Culture ticket - Dataset I, coefficients for Table 10

\begin{tabular}{|c|c|c|c|c|}
\hline \multicolumn{5}{|c|}{ Dependent Variable: Supporting Culture Ticket } \\
\hline & (1) & $(2)$ & $(3)$ & (4) \\
\hline Rarely (1 or $2 /$ year) & $\begin{array}{c}0.982^{* * *} \\
(0.09)\end{array}$ & $\begin{array}{c}0.902^{* * *} \\
(0.10)\end{array}$ & $\begin{array}{c}0.961^{* * *} \\
(0.10)\end{array}$ & $\begin{array}{c}0.931^{* * *} \\
(0.12)\end{array}$ \\
\hline Sometimes ( 3 to $5 /$ year) & $\begin{array}{c}1.744^{* * *} \\
(0.15)\end{array}$ & $\begin{array}{c}1.643^{* * *} \\
(0.16)\end{array}$ & $\begin{array}{c}1.677^{* * *} \\
(0.17)\end{array}$ & $\begin{array}{c}1.664^{* * *} \\
(0.22)\end{array}$ \\
\hline Often (6 to $10 /$ year) & $\begin{array}{c}2.164^{* * *} \\
(0.33)\end{array}$ & $\begin{array}{c}2.083^{* * *} \\
(0.34)\end{array}$ & $\begin{array}{c}2.138^{* * *} \\
(0.35)\end{array}$ & $\begin{array}{c}1.901^{* * *} \\
(0.44)\end{array}$ \\
\hline Very often $(>10 /$ year $)$ & $\begin{array}{c}1.915^{* * *} \\
(0.30)\end{array}$ & $\begin{array}{c}1.717^{* * *} \\
(0.31)\end{array}$ & $\begin{array}{c}1.855^{* * *} \\
(0.36)\end{array}$ & $\begin{array}{c}1.523^{* *} \\
(0.48)\end{array}$ \\
\hline Savings of others & & $\begin{array}{c}0.727^{* * *} \\
(0.11)\end{array}$ & $\begin{array}{c}0.726^{* * *} \\
(0.11)\end{array}$ & $\begin{array}{c}0.405^{* *} \\
(0.15)\end{array}$ \\
\hline Female & & & $\begin{array}{c}0.220^{*} \\
(0.09)\end{array}$ & $\begin{array}{c}0.085 \\
(0.10)\end{array}$ \\
\hline Freshman & & & $\begin{array}{c}0.327^{* *} \\
(0.10)\end{array}$ & $\begin{array}{c}0.338^{* *} \\
(0.12)\end{array}$ \\
\hline Others should go & & & & $\begin{array}{c}1.293^{* * *} \\
(0.19)\end{array}$ \\
\hline Strengthening local culture & & & & $\begin{array}{c}1.344^{* * *} \\
(0.13)\end{array}$ \\
\hline Constant & $\begin{array}{c}-0.463^{* * *} \\
(0.05)\end{array}$ & $\begin{array}{c}-0.536^{* * *} \\
(0.06)\end{array}$ & $\begin{array}{c}-0.767^{* * *} \\
(0.08)\end{array}$ & $\begin{array}{c}-1.141^{* * *} \\
(0.10)\end{array}$ \\
\hline Pseudo $\mathrm{R}^{2}$ & 0.192 & 0.215 & 0.215 & 0.440 \\
\hline Log Likelihood & -664.7 & -599.2 & -571.1 & -378.7 \\
\hline Observations & 1189 & 1110 & 1055 & 988 \\
\hline
\end{tabular}


Table A.4: Bahn ticket - Dataset II, coefficients for Table 11

\begin{tabular}{|c|c|c|c|c|c|}
\hline \multicolumn{6}{|c|}{ Dependent Variable: Supporting Bahn Ticket } \\
\hline & $(1)$ & $(2)$ & $(3)$ & $(4)$ & $(5)$ \\
\hline \multirow[t]{2}{*}{ Log savings } & $0.258^{* * *}$ & $0.215^{* * *}$ & $0.230^{* * *}$ & $0.268^{* * *}$ & $0.271^{* * *}$ \\
\hline & $(0.02)$ & $(0.02)$ & $(0.02)$ & $(0.03)$ & $(0.03)$ \\
\hline \multirow[t]{2}{*}{ Leisure/work } & & 0.244 & 0.104 & 0.143 & 0.158 \\
\hline & & $(0.24)$ & $(0.26)$ & $(0.28)$ & $(0.28)$ \\
\hline \multirow[t]{2}{*}{ Visiting others } & & $1.000 * * *$ & $1.044 * * *$ & $0.951 * * *$ & $0.975 * * *$ \\
\hline & & $(0.11)$ & $(0.12)$ & $(0.13)$ & $(0.13)$ \\
\hline \multirow[t]{2}{*}{ Female } & & & 0.175 & 0.149 & 0.145 \\
\hline & & & $(0.12)$ & $(0.13)$ & $(0.13)$ \\
\hline \multirow[t]{2}{*}{ Freshman } & & & $0.326^{*}$ & $0.437^{*}$ & $0.465^{*}$ \\
\hline & & & $(0.16)$ & $(0.18)$ & $(0.19)$ \\
\hline \multirow[t]{2}{*}{ Altruist $(-)$} & & & & $-0.538^{* *}$ & $-0.526^{* *}$ \\
\hline & & & & $(0.18)$ & $(0.18)$ \\
\hline \multirow[t]{2}{*}{ Altruist $(+)$} & & & & $1.023 * * *$ & $1.031 * * *$ \\
\hline & & & & $(0.17)$ & $(0.17)$ \\
\hline \multirow[t]{2}{*}{ Protest } & & & & & -0.282 \\
\hline & & & & & $(0.15)$ \\
\hline \multirow[t]{2}{*}{ Constant } & $-0.220 * * *$ & $-0.728 * * *$ & $-0.872 * * *$ & $-1.112^{* * *}$ & $-1.062^{* * *}$ \\
\hline & $(0.07)$ & $(0.09)$ & $(0.12)$ & $(0.15)$ & $(0.15)$ \\
\hline Pseudo $\mathrm{R}^{2}$ & 0.225 & 0.306 & 0.333 & 0.434 & 0.438 \\
\hline Log Likelihood & -395.7 & -351.7 & -307.4 & -236.0 & -234.2 \\
\hline Observations & 818 & 810 & 741 & 669 & 669 \\
\hline
\end{tabular}

Table A.5: Taking part - Dataset II, coefficients for Table 12

\begin{tabular}{|c|c|c|c|c|c|c|}
\hline \multicolumn{7}{|c|}{ Dependent Variable: Taking Part in Referendum } \\
\hline & $(1)$ & $(2)$ & $(3)$ & $(4)$ & $(5)$ & $(6)$ \\
\hline & all & all & all & all & savings $\geq$ price & savings $<$ price \\
\hline \multirow[t]{2}{*}{ Log stakes } & $0.206^{* * *}$ & $0.205^{* * *}$ & $0.223^{* * *}$ & $0.228 * * *$ & $0.171^{* *}$ & 0.109 \\
\hline & $(0.04)$ & $(0.04)$ & $(0.04)$ & $(0.04)$ & $(0.06)$ & $(0.10)$ \\
\hline \multirow[t]{2}{*}{ Leisure/work } & & -0.047 & -0.021 & -0.025 & -0.050 & -0.007 \\
\hline & & $(0.16)$ & $(0.18)$ & $(0.18)$ & $(0.31)$ & $(0.22)$ \\
\hline \multirow[t]{2}{*}{ Visiting others } & & 0.120 & 0.101 & 0.095 & 0.140 & -0.024 \\
\hline & & $(0.08)$ & $(0.09)$ & $(0.09)$ & $(0.18)$ & $(0.10)$ \\
\hline \multirow[t]{2}{*}{ Female } & & & $-0.300 * * *$ & $-0.298 * * *$ & $-0.396^{* *}$ & $-0.225^{*}$ \\
\hline & & & $(0.08)$ & $(0.08)$ & $(0.14)$ & $(0.10)$ \\
\hline \multirow[t]{2}{*}{ Freshman } & & & $0.489 * * *$ & $0.481^{* * *}$ & 0.350 & $0.581 * * *$ \\
\hline & & & $(0.13)$ & $(0.13)$ & $(0.20)$ & $(0.17)$ \\
\hline \multirow[t]{2}{*}{ Protest } & & & & $0.279^{* *}$ & 0.252 & $0.265^{*}$ \\
\hline & & & & $(0.10)$ & $(0.17)$ & $(0.13)$ \\
\hline \multirow[t]{2}{*}{ Constant } & $-0.479 * *$ & $-0.542^{* *}$ & $-0.502^{*}$ & $-0.578^{* *}$ & -0.096 & -0.128 \\
\hline & $(0.18)$ & $(0.18)$ & $(0.20)$ & $(0.20)$ & $(0.34)$ & $(0.47)$ \\
\hline Pseudo $\mathrm{R}^{2}$ & 0.023 & 0.026 & 0.050 & 0.056 & 0.046 & 0.027 \\
\hline Log Likelihood & -713.1 & -700.8 & -625.6 & -622.0 & -213.2 & -403.5 \\
\hline Observations & 1189 & 1174 & 1075 & 1075 & 449 & 626 \\
\hline
\end{tabular}

Probit estimation, coefficients, standard errors in parentheses. Regression (5): only students whose savings cover ticket costs (winners), regression (6): only students whose savings do not cover ticket costs. $* p<0.05, * * p<0.01, * * * p<0.001$ 
Table A.6: Taking part, reduced sample - Dataset II, coefficients for Table 13

\begin{tabular}{|c|c|c|c|c|c|c|}
\hline \multicolumn{7}{|c|}{ Dependent Variable: Taking Part in Referendum } \\
\hline & $(1)$ & $(2)$ & $(3)$ & $(4)$ & $(5)$ & $(6)$ \\
\hline Bottom & $95 \%$ & $90 \%$ & $85 \%$ & $80 \%$ & $75 \%$ & $70 \%$ \\
\hline \multirow[t]{2}{*}{ Log stakes } & $0.235^{* * *}$ & $0.204^{* * *}$ & $0.188^{* * *}$ & $0.140^{*}$ & 0.078 & 0.030 \\
\hline & $(0.05)$ & $(0.05)$ & $(0.06)$ & $(0.06)$ & $(0.07)$ & $(0.08)$ \\
\hline \multirow{2}{*}{ Leisure/work } & -0.018 & -0.032 & -0.059 & -0.030 & -0.014 & -0.074 \\
\hline & $(0.18)$ & $(0.19)$ & $(0.19)$ & $(0.19)$ & $(0.20)$ & $(0.21)$ \\
\hline \multirow[t]{2}{*}{ Visiting others } & 0.110 & 0.110 & 0.121 & 0.101 & 0.062 & 0.018 \\
\hline & $(0.09)$ & $(0.09)$ & $(0.09)$ & $(0.09)$ & $(0.09)$ & $(0.10)$ \\
\hline \multirow[t]{2}{*}{ Female } & $-0.288 * * *$ & $-0.282^{* *}$ & $-0.270^{* *}$ & $-0.244^{* *}$ & $-0.252^{* *}$ & $-0.209 *$ \\
\hline & $(0.09)$ & $(0.09)$ & $(0.09)$ & $(0.09)$ & $(0.09)$ & $(0.09)$ \\
\hline \multirow[t]{2}{*}{ Freshman } & $0.497 * * *$ & $0.494 * * *$ & $0.463^{* * *}$ & $0.496^{* * *}$ & $0.484^{* *}$ & $0.469 * *$ \\
\hline & $(0.14)$ & $(0.14)$ & $(0.14)$ & $(0.15)$ & $(0.15)$ & $(0.16)$ \\
\hline \multirow[t]{2}{*}{ Protest } & $0.304 * *$ & $0.305^{* *}$ & $0.288^{* *}$ & $0.285^{*}$ & $0.313^{* *}$ & $0.300^{*}$ \\
\hline & $(0.11)$ & $(0.11)$ & $(0.11)$ & $(0.11)$ & $(0.11)$ & $(0.12)$ \\
\hline \multirow[t]{2}{*}{ Constant } & $-0.630 * *$ & $-0.501^{*}$ & -0.438 & -0.248 & 0.024 & 0.219 \\
\hline & $(0.22)$ & $(0.24)$ & $(0.26)$ & $(0.29)$ & $(0.32)$ & $(0.35)$ \\
\hline Pseudo $\mathrm{R}^{2}$ & 0.052 & 0.044 & 0.036 & 0.030 & 0.027 & 0.022 \\
\hline Log Likelihood & -594.8 & -580.7 & -558.1 & -535.0 & -509.4 & -486.7 \\
\hline Observations & 1011 & 967 & 912 & 858 & 806 & 761 \\
\hline
\end{tabular}

Probit estimation, coefficients, standard errors in parentheses. Columns show percentiles with respect to stakes, e column (1) contains those observations who belong to the bottom $95 \%$ with respect to stakes. ${ }^{*} p<0.05,{ }^{* *} p<0.01,{ }^{* * *} p<0.001$. 


\section{A.IV Political parties and fields of study}

Table A.7: General political preferences - Dataset I, coefficients

\begin{tabular}{|c|c|c|c|}
\hline \multicolumn{4}{|c|}{ Dependent Variable: Supporting Ticket } \\
\hline & $\begin{array}{c}(1) \\
\text { Train }\end{array}$ & $\begin{array}{l}\text { (2) } \\
\text { Bus }\end{array}$ & $\begin{array}{c}\text { (3) } \\
\text { Culture }\end{array}$ \\
\hline Rarely $\diamond$ & $\begin{array}{c}1.034^{* * *} \\
(0.21)\end{array}$ & $\begin{array}{c}0.585^{* * *} \\
(0.11)\end{array}$ & $\begin{array}{c}0.893^{* * *} \\
(0.14)\end{array}$ \\
\hline Sometimes $\diamond$ & $\begin{array}{c}1.930^{* * *} \\
(0.22)\end{array}$ & $\begin{array}{c}1.083^{* * *} \\
(0.15)\end{array}$ & $\begin{array}{c}1.712^{* * *} \\
(0.25)\end{array}$ \\
\hline Often $\diamond$ & $\begin{array}{c}2.408^{* * *} \\
(0.26)\end{array}$ & $\begin{array}{c}1.626^{* * *} \\
(0.18)\end{array}$ & $\begin{array}{c}1.804^{* * * *} \\
(0.44)\end{array}$ \\
\hline Very often $\diamond$ & $\begin{array}{c}2.344^{* * *} \\
(0.25)\end{array}$ & $\begin{array}{c}2.104^{* * *} \\
(0.20)\end{array}$ & $\begin{array}{c}1.981 * * * \\
(0.60)\end{array}$ \\
\hline Savings of others & $\begin{array}{c}0.690^{* * *} \\
(0.15)\end{array}$ & $\begin{array}{c}0.538^{* * *} \\
(0.12)\end{array}$ & $\begin{array}{c}0.366^{*} \\
(0.16)\end{array}$ \\
\hline Female & $\begin{array}{c}0.332^{*} \\
(0.13)\end{array}$ & $\begin{array}{c}0.040 \\
(0.10)\end{array}$ & $\begin{array}{l}-0.049 \\
(0.12)\end{array}$ \\
\hline Freshman & $\begin{array}{r}-0.176 \\
(0.14)\end{array}$ & $\begin{array}{c}0.272^{* *} \\
(0.10)\end{array}$ & $\begin{array}{c}0.346^{*} \\
(0.14)\end{array}$ \\
\hline Environment & $\begin{array}{c}0.663^{* * *} * \\
(0.19)\end{array}$ & & \\
\hline Strengthening bus system & & $\begin{array}{c}1.225^{* * *} \\
(0.20)\end{array}$ & \\
\hline Others should go & & & $\begin{array}{c}1.267^{* * *} \\
(0.20)\end{array}$ \\
\hline Strengthening local culture & & & $\begin{array}{c}1.287^{* * *} \\
(0.15)\end{array}$ \\
\hline Social Democrats & $\begin{array}{c}-0.104 \\
(0.16)\end{array}$ & $\begin{array}{c}0.017 \\
(0.12)\end{array}$ & $\begin{array}{c}0.628^{* * *} \\
(0.15)\end{array}$ \\
\hline Liberal Democrats & $\begin{array}{l}-0.562 \\
(0.29)\end{array}$ & $\begin{array}{l}-0.232 \\
(0.27)\end{array}$ & $\begin{array}{l}0.171 \\
(0.27)\end{array}$ \\
\hline Green & $\begin{array}{l}-0.104 \\
(0.17)\end{array}$ & $\begin{array}{l}-0.109 \\
(0.13)\end{array}$ & $\begin{array}{c}0.611^{* * * *} \\
(0.16)\end{array}$ \\
\hline Left & $\begin{array}{l}-0.065 \\
(0.34)\end{array}$ & $\begin{array}{c}0.037 \\
(0.25)\end{array}$ & $\begin{array}{c}0.970^{* *} \\
(0.34)\end{array}$ \\
\hline Other parties & $\begin{array}{c}0.153 \\
(0.31)\end{array}$ & $\begin{array}{l}-0.076 \\
(0.23)\end{array}$ & $\begin{array}{l}0.260 \\
(0.28)\end{array}$ \\
\hline Constant & $\begin{array}{c}-0.884 * * * \\
(0.23)\end{array}$ & $\begin{array}{c}-0.935^{* * *} \\
(0.11)\end{array}$ & $\begin{array}{c}-1.486^{* * *} \\
(0.14) \\
\end{array}$ \\
\hline Pseudo $\mathrm{R}^{2}$ & 0.371 & 0.281 & 0.466 \\
\hline Log Likelihood & -246.5 & -477.1 & -312.7 \\
\hline Observations & 1000 & 958 & 858 \\
\hline
\end{tabular}

Probit estimation, coefficients, standard errors in parentheses.

$\diamond$ Definitions of the intensity of use differ: rarely, sometimes, often,

very often corresponds to $\leq 5 /$ year, monthly, weekly, $\geq 2$ /week

for the train ticket, 1 or $2 /$ semester, monthly, weekly, $\geq 2 /$ week during lecture period for the bus ticket and 1 or 2 /year, 3 to 5 /year, 6 to 10 /year, $>10$ year for the culture ticket. The base category for the party preferences is Christian Democrats. ${ }^{*} p<0.05,{ }^{* *} p<0.01,{ }^{* * *} p<0.001$ 
Table A.8: Fields of study - Dataset I, coefficients

\begin{tabular}{|c|c|c|c|}
\hline \multicolumn{4}{|c|}{ Dependent Variable: Supporting Ticket } \\
\hline & $\begin{array}{c}\text { (1) } \\
\text { Train }\end{array}$ & $\begin{array}{l}\text { (2) } \\
\text { Bus }\end{array}$ & $\begin{array}{c}(3) \\
\text { Culture }\end{array}$ \\
\hline Rarely $\triangleright$ & $\begin{array}{c}1.083^{* * *} \\
(0.20)\end{array}$ & $\begin{array}{c}0.640^{* * *} \\
(0.11)\end{array}$ & $\begin{array}{c}0.859^{* * *} \\
(0.13)\end{array}$ \\
\hline Sometimes $\diamond$ & $\begin{array}{c}2.010^{* * *} \\
(0.21)\end{array}$ & $\begin{array}{c}1.174 * * * \\
(0.14)\end{array}$ & $\begin{array}{c}1.642^{* * *} \\
(0.23)\end{array}$ \\
\hline Often $\diamond$ & $\begin{array}{c}2.402 * * * \\
(0.24)\end{array}$ & $\begin{array}{c}1.644 * * * \\
(0.17)\end{array}$ & $\begin{array}{c}1.755^{* * *} \\
(0.45)\end{array}$ \\
\hline Very often $\diamond$ & $\begin{array}{c}2.438^{* * *} \\
(0.25)\end{array}$ & $\begin{array}{c}2.237^{* * *} \\
(0.19)\end{array}$ & $\begin{array}{c}1.430^{* *} \\
(0.51)\end{array}$ \\
\hline Savings of others & $0.632^{* * *}$ & $0.500^{* * *}$ & $0.398^{* *}$ \\
\hline Female & $\begin{array}{c}0.186 \\
(0.13)\end{array}$ & $\begin{array}{c}0.025 \\
(0.09)\end{array}$ & $\begin{array}{l}0.015 \\
(0.11)\end{array}$ \\
\hline Freshman & $\begin{array}{l}-0.117 \\
(0.13)\end{array}$ & $\begin{array}{l}0.242^{*} \\
(0.10)\end{array}$ & $\begin{array}{l}0.319^{*} \\
(0.13)\end{array}$ \\
\hline Environment & $\begin{array}{c}0.707^{* * *} \\
(0.18)\end{array}$ & & \\
\hline Strengthening bus system & & $\begin{array}{c}1.177^{* * *} \\
(0.18)\end{array}$ & \\
\hline Others should go & & & $\begin{array}{c}1.333^{* * * *} \\
(0.19)\end{array}$ \\
\hline Strengthening local culture & & & $\begin{array}{c}1.317^{* * *} \\
(0.14)\end{array}$ \\
\hline Social sciences & $\begin{array}{c}0.149 \\
(0.17)\end{array}$ & $\begin{array}{l}0.086 \\
(0.12)\end{array}$ & $\begin{array}{c}0.560^{* * *} \\
(0.14)\end{array}$ \\
\hline Forestry/Agriculture & $\begin{array}{c}-0.623^{* *} \\
(0.22)\end{array}$ & $\begin{array}{c}0.262 \\
(0.19)\end{array}$ & $\begin{array}{r}-0.147 \\
(0.24)\end{array}$ \\
\hline Humanities & $\begin{array}{l}0.210 \\
(0.16)\end{array}$ & $\begin{array}{l}0.040 \\
(0.11)\end{array}$ & $\begin{array}{l}0.343^{*} \\
(0.14)\end{array}$ \\
\hline Geology/Geography & $\begin{array}{l}0.016 \\
(0.41)\end{array}$ & $\begin{array}{l}0.082 \\
(0.26)\end{array}$ & $\begin{array}{l}0.545 \\
(0.32)\end{array}$ \\
\hline Law & $\begin{array}{r}-0.046 \\
(0.20)\end{array}$ & $\begin{array}{l}0.318^{*} \\
(0.15)\end{array}$ & $\begin{array}{l}0.089 \\
(0.17)\end{array}$ \\
\hline Natural sciences & $\begin{array}{l}-0.191 \\
(0.21)\end{array}$ & $\begin{array}{l}-0.026 \\
(0.17)\end{array}$ & $\begin{array}{l}0.440^{*} \\
(0.20)\end{array}$ \\
\hline Other fields & $\begin{array}{c}0.397 \\
(0.47)\end{array}$ & $\begin{array}{l}-0.146 \\
(0.25)\end{array}$ & $\begin{array}{l}0.240 \\
(0.33)\end{array}$ \\
\hline Constant & $\begin{array}{c}-0.949 * * * \\
(0.21)\end{array}$ & $\begin{array}{c}-1.039 * * * \\
(0.10)\end{array}$ & $\begin{array}{c}-1.336 * * * \\
(0.12)\end{array}$ \\
\hline Pseudo $\mathrm{R}^{2}$ & 0.381 & 0.290 & 0.460 \\
\hline Log Likelihood & -270.4 & -534.9 & -364.3 \\
\hline Observations & 1143 & 1088 & 986 \\
\hline
\end{tabular}

Probit estimation, coefficients, standard errors in parentheses.

$\diamond$ Definitions of the intensity of use differ: rarely, sometimes, often,

very often corresponds to $\leq 5 /$ year, monthly, weekly, $\geq 2$ /week

for the train ticket, 1 or $2 /$ semester, monthly, weekly, $\geq 2$ /week

during lecture period for the bus ticket and 1 or $2 /$ year, 3 to $5 /$ year, 6 to $10 /$ year, $>10 /$ year for the culture ticket. The base categories for the fields of study is economic sciences. ${ }^{*} p<0.05,{ }^{* *} p<0.01,{ }^{* * *} p<0.001$ 
Table A.9: Political preferences and fields of study - Dataset I, coefficients

\begin{tabular}{|c|c|c|c|}
\hline \multicolumn{4}{|c|}{ Dependent Variable: Supporting Ticket } \\
\hline & $\begin{array}{c}\text { (1) } \\
\text { Train }\end{array}$ & $\begin{array}{l}\text { (2) } \\
\text { Bus }\end{array}$ & $\begin{array}{c}(3) \\
\text { Culture }\end{array}$ \\
\hline Rarely $\diamond$ & $\begin{array}{c}1.060^{* * *} \\
(0.22)\end{array}$ & $\begin{array}{c}0.583^{* * *} \\
(0.12)\end{array}$ & $\begin{array}{c}0.853^{* * *} \\
(0.14)\end{array}$ \\
\hline Sometimes $\diamond$ & $\begin{array}{c}1.963^{* * * *} \\
(0.22)\end{array}$ & $\begin{array}{c}1.081^{* * *} \\
(0.15)\end{array}$ & $\begin{array}{c}1.728^{* * * *} \\
(0.25)\end{array}$ \\
\hline Often $\diamond$ & $\begin{array}{c}2.475^{* * *} \\
(0.26)\end{array}$ & $\begin{array}{c}1.619^{* * *} \\
(0.18)\end{array}$ & $\begin{array}{c}1.762^{* * *} \\
(0.45)\end{array}$ \\
\hline Very often $\diamond$ & $\begin{array}{c}2.331^{* * * *} \\
(0.26)\end{array}$ & $\begin{array}{c}2.112^{* * *} \\
(0.20)\end{array}$ & $\begin{array}{c}1.971^{* *} \\
(0.63)\end{array}$ \\
\hline Savings of others & $\begin{array}{c}0.718^{* * *} \\
(0.16)\end{array}$ & $\begin{array}{c}0.529 * * * \\
(0.12)\end{array}$ & $\begin{array}{l}0.361^{*} \\
(0.16)\end{array}$ \\
\hline Female & $\begin{array}{c}0.261 \\
(0.14)\end{array}$ & $\begin{array}{c}0.035 \\
(0.10)\end{array}$ & $\begin{array}{l}-0.062 \\
(0.12)\end{array}$ \\
\hline Freshman & $\begin{array}{r}-0.178 \\
(0.14)\end{array}$ & $\begin{array}{c}0.275^{* *} \\
(0.10)\end{array}$ & $\begin{array}{l}0.348^{*} \\
(0.14)\end{array}$ \\
\hline Environment & $\begin{array}{c}0.644^{* * *} \\
(0.19)\end{array}$ & & \\
\hline Strengthening bus system & & $\begin{array}{c}1.225^{* * *} \\
(0.20)\end{array}$ & \\
\hline Others should go & & & $\begin{array}{c}1.316^{* * *} \\
(0.20)\end{array}$ \\
\hline Strengthening local culture & & & $\begin{array}{c}1.294^{* * *} \\
(0.15)\end{array}$ \\
\hline Social sciences & $\begin{array}{c}0.172 \\
(0.18)\end{array}$ & $\begin{array}{c}0.127 \\
(0.12)\end{array}$ & $\begin{array}{c}0.446^{* *} \\
(0.15)\end{array}$ \\
\hline Forestry/Agriculture & $\begin{array}{c}-0.661^{* *} \\
(0.24)\end{array}$ & $\begin{array}{l}0.165 \\
(0.21)\end{array}$ & $\begin{array}{l}-0.004 \\
(0.27)\end{array}$ \\
\hline Humanities & $\begin{array}{c}0.201 \\
(0.17)\end{array}$ & $\begin{array}{l}0.033 \\
(0.12)\end{array}$ & $\begin{array}{l}0.176 \\
(0.16)\end{array}$ \\
\hline Geology/Geography & $\begin{array}{c}0.013 \\
(0.42)\end{array}$ & $\begin{array}{c}0.267 \\
(0.28)\end{array}$ & $\begin{array}{c}0.608 \\
(0.36)\end{array}$ \\
\hline Law & $\begin{array}{l}-0.097 \\
(0.21)\end{array}$ & $\begin{array}{c}0.414^{*} \\
(0.16)\end{array}$ & $\begin{array}{c}0.073 \\
(0.18)\end{array}$ \\
\hline Natural sciences & $\begin{array}{l}-0.367 \\
(0.23)\end{array}$ & $\begin{array}{l}0.059 \\
(0.18)\end{array}$ & $\begin{array}{c}0.379 \\
(0.22)\end{array}$ \\
\hline Other fields & $\begin{array}{l}0.328 \\
(0.52)\end{array}$ & $\begin{array}{l}-0.065 \\
(0.28)\end{array}$ & $\begin{array}{c}0.231 \\
(0.38)\end{array}$ \\
\hline Social Democrats & $\begin{array}{l}-0.231 \\
(0.17)\end{array}$ & $\begin{array}{c}0.046 \\
(0.13)\end{array}$ & $\begin{array}{c}0.541 * * * \\
(0.16)\end{array}$ \\
\hline Liberal Democrats & $\begin{array}{c}-0.674^{*} \\
(0.29)\end{array}$ & $\begin{array}{l}-0.218 \\
(0.27)\end{array}$ & $\begin{array}{c}0.178 \\
(0.27)\end{array}$ \\
\hline Green & $\begin{array}{l}-0.221 \\
(0.19)\end{array}$ & $\begin{array}{l}-0.081 \\
(0.13)\end{array}$ & $\begin{array}{c}0.466^{* *} \\
(0.17)\end{array}$ \\
\hline Left & $\begin{array}{l}-0.217 \\
(0.35)\end{array}$ & $\begin{array}{l}0.058 \\
(0.26)\end{array}$ & $\begin{array}{c}0.930^{* *} \\
(0.36)\end{array}$ \\
\hline Other parties & $\begin{array}{c}0.106 \\
(0.33)\end{array}$ & $\begin{array}{r}-0.037 \\
(0.24)\end{array}$ & $\begin{array}{c}0.238 \\
(0.29)\end{array}$ \\
\hline Constant & $\begin{array}{c}-0.780^{* *} \\
(0.24)\end{array}$ & $\begin{array}{c}-1.057^{* * *} \\
(0.13)\end{array}$ & $\begin{array}{c}-1.612^{* * *} \\
(0.16)\end{array}$ \\
\hline Pseudo $\mathrm{R}^{2}$ & 0.391 & 0.287 & 0.477 \\
\hline Log likelihood & -238.6 & -472.9 & -306.0 \\
\hline Observations & 999 & 957 & 857 \\
\hline
\end{tabular}

Probit estimation, coefficients, standard errors in parentheses.

$\diamond$ Definitions of the intensity of use differ: rarely, sometimes, often, very often corresponds to $\leq 5 /$ year, monthly, weekly, $\geq 2$ /week for the train ticket, 1 or $2 /$ semester, monthly, weekly, 2 /week during lecture period for the bus ticket and 1 or 2 year, 3 to 5 /year, 6 to 10 /year, $>10$ /year for the culture ticket. The base categories for the fields of study and party preferences are economic sciences and Christian Democrats, respectively. ${ }^{*} p<0.05,{ }^{* *} p<0.01,{ }^{* * *} p<0.001$ 


\section{References}

Alesina, Alberto and George-Marios Angeletos, "Fairness and Redistribution," American Economic Review, 2005, 95 (4), 960-980.

Andersen, Jørgen J., Jon H. Fiva, and Gisle J. Natvik, "Voting when the Stakes are High," Journal of Public Economics, 2014, 110, 157-166.

Ansell, Ben, "The Political Economy of Ownership: Housing Markets and the Welfare State," American Political Science Review, 2014, 108 (2), 383-402.

Balafoutas, Loukas, Martin G. Kocher, Louis Putterman, and Matthias Sutter, "Equality, Equity and Incentives: An Experiment," European Economic Review, 2013, 60, 32-51.

Barro, Robert J., "The Control of Politicians: An Economic Model," Public Choice, 1973, 14 (1), 19-42.

Brennan, Geoffrey and Alan Hamlin, "Expressive Voting and Electoral Equilibrium," Public Choice, 1998, 95 (1-2), 149-175.

- and James Buchanan, "Voter Choice: Evaluating Political Alternatives," American Behavioral Scientist, 1984, 28 (2), 185-201.

California State Board of Equalization, "California Property Tax: An Overview," Publication 29, November 2012, available at http://www.boe.ca. gov/proptaxes/pdf/pub29.pdf (accessed September 28th, 2014) 2012.

Carlsson, Fredrik and Olof Johansson-Stenman, "Why Do You Vote and Vote as You Do?," Kyklos, 2010, 63 (4), 495-516.

Coate, Stephen and Michael Conlin, "A Group Rule: Utilitarian Approach to Voter Turnout: Theory and Evidence," American Economic Review, 2004, 94 (5), $1476-1504$.

_ , _, and Andrea Moro, "The Performance of Pivotal-Voter Models in SmallScale Elections: Evidence from Texas Liquor Referenda," Journal of Public Economics, 2008, 92 (3-4), 582-596.

Coates, Dennis and Brad R. Humphreys, "Proximity Benefits and Voting on Stadium and Arena Subsidies," Journal of Urban Economics, 2006, 59 (2), 285299. 
De La O, Ana L., "Do Conditional Cash Transfers Affect Electoral Behavior? Evidence from a Randomized Experiment in Mexico," American Journal of Political Science, 2013, 57 (1), 1-14.

Deacon, Robert and Perry Shapiro, "Private Preference for Collective Goods Revealed through Voting on Referenda," American Economic Review, 1975, 65 (5), 943-955.

DellaVigna, Stefano and Ulrike Malmendier, "Paying not to Go to the Gym," American Economic Review, 2006, 96 (3), 694-719.

Dixit, Avinash and John Londregan, "The Determinants of Success of Special Interests in Redistributive Politics," Journal of Politics, 1996, 58 (4), 1132-1155.

Downs, Anthony, An Economic Theory of Democracy, New York: Harper and Row Publishers, 1957.

Elinder, Mikael, Henrik Jordahl, and Panu Poutvaara, "Promises, Policies and Pocketbook Voting," European Economic Review, 2015, 75, 177-194.

Epple, Dennis N. and Richard E. Romano, "Public Provision of Private Goods," Journal of Political Economy, 1996, 104 (1), 57-84.

_ , Thomas Romer, and Holger Sieg, "Interjurisdictional Sorting and Majority Rule: An Empirical Analysis," Econometrica, 2001, 69 (6), 1437-1465.

Fehr, Ernst and Klaus M. Schmidt, "A Theory of Fairness, Competition, and Cooperation," Quarterly Journal of Economics, 1999, 114 (3), 817-868.

Feld, Lars P. and Gebhard Kirchgässner, "The Political Economy of Direct Legislation: Direct Democracy and Local Decision-Making," Economic Policy, 2001, 16 (33), 329-367.

- and John G. Matsusaka, "Budget Referendums and Government Spending: Evidence from Swiss Cantons," Journal of Public Economics, 2003, 87 (12), 27032724.

Fiorina, Morris P., "Economic Retrospective Voting in American National Elections: A Micro-Analysis," American Journal of Political Science, 1978, 22 (2), $426-443$.

_, Retrospective Voting in American National Elections, New Haven: Yale University Press, 1981. 
Fong, Christina, "Social Preferences, Self-Interest, and the Demand for Redistribution," Journal of Public Economics, 2001, 82 (2), 225-246.

Funk, Patricia, "Social Incentives and Voter Turnout: Evidence from the Swiss Mail Ballot System," Journal of the European Economic Association, 2010, 8 (5), 1077-1103.

- and Christina Gathmann, "Does Direct Democracy Reduce the Size of Government? New Evidence from Historical Data, 1890-2000," Economic Journal, 2011, 121 (557), 1252-1280.

Gerber, Alan S., Donald P. Green, and Christopher W. Larimer, "Social Pressure and Voter Turnout: Evidence from a Large-Scale Field Experiment," American Political Science Review, 2008, 102 (1), 33-48.

Harsanyi, John C., "Rule Utilitarianism, Rights, Obligations and the Theory of Rational Behavior," Theory and Decision, 1980, 12 (2), 115-133.

Hillman, Arye L., "Expressive Behavior in Economics and Politics," European Journal of Political Economy, 2010, 26 (4), 403-418.

Key, Valdimer O., The Responsible Electorate, Cambridge: Belknap Press of Harvard University Press, 1966.

Kinder, Donald R. and D. Roderick Kiewiet, "Economic Discontent and Political Behavior: The Role of Personal Grievances and Collective Economic Judgments in Congressional Voting," American Journal of Political Science, 1979, 23 (3), 495-527.

Kriner, Douglas L. and Andrew Reeves, "The Influence of Federal Spending on Presidential Elections," American Political Science Review, 2012, 106 (2), 348366.

Levitt, Steven D. and James M. Snyder, "The Impact of Federal Spending on House Election Outcomes," Journal of Political Economy, 1997, 105 (1), 30-53.

Lewis-Beck, Michael S. and Mary Stegmaier, "Economic Models of Voting," in Russel J. Dalton and Hans-Dieter Klingemann, eds., The Oxford Handbook of Political Behavior, 2007, pp. 518-537.

Lindbeck, Assar and Jörgen W. Weibull, "A Model of Political Equilibrium in a Representative Democracy," Journal of Public Economics, 1993, 51 (2), 195-209. 
Manacorda, Marco, Edward Miguel, and Andrea Vigorito, "Government Transfers and Political Support," American Economic Journal: Applied Economics, 2011, 3 (3), 1-28.

Margalit, Yotam, "Explaining Social Policy Preferences: Evidence from the Great Recession," American Political Science Review, 2013, 107 (1), 80-103.

Markus, Gregory B., "The Impact of Personal and National Economic Conditions on the Presidential Vote: A Pooled Cross-Sectional Analysis," American Journal of Political Science, 1988, 32 (1), 137-154.

Matsusaka, John G., "Fiscal Effects of the Voter Initiative: Evidence from the Last 30 Years," Journal of Political Economy, 1995, 103 (3), 587-623.

Meltzer, Allan H. and Scott F. Richard, "A Rational Theory of the Size of Government," Journal of Political Economy, 1981, 89 (5), 914-927.

Messer, Kent D., Gregory L. Poe, Daniel Rondeau, William D. Schulze, and Christian A. Vossler, "Social Preferences and Voting: An Exploration Using a Novel Preference Revealing Mechanism," Journal of Public Economics, 2010, 94 (3-4), 308-317.

Pop-Eleches, Cristian and Grigore Pop-Eleches, "Targeted Government Spending and Political Preferences," Quarterly Journal of Political Science, 2012, $7(3), 285-320$.

Potrafke, Niklas, "Evidence on the Political Principal-Agent Problem from Voting on Public Finance for Concert Halls," Constitutional Political Economy, 2013, 24 (3), 215-238.

Richter, Kaspar, "Wage Arrears and Economic Voting in Russia," American Political Science Review, 2006, 100 (1), 133-145.

Riker, William H. and Peter C. Ordeshook, "A Theory of the Calculus of Voting," American Political Science Review, 1968, 62 (1), 25-42.

Rogoff, Kenneth and Anne Sibert, "Elections and Macroeconomic Policy Cycles," The Review of Economic Studies, 1988, 55 (1), 1-16.

Romer, Thomas, Howard Rosenthal, and Vincent G. Munley, "Economic Incentives and Political Institutions: Spending and Voting in School Budget Referenda," Journal of Public Economics, 1992, 49 (1), 1-33. 
Rousseau, Jean-Jacques, On the Social Contract, Mineola, New York: Dover Publications, 2012 [1762].

Schumpeter, Joseph A., Capitalism, Socialism and Democracy, London, New York: Routledge, 1994 [1942].

Thachil, Tariq, "Elite Parties and Poor Voters: Theory and Evidence from India," American Political Science Review, 2014, 108 (2), 454-477.

Tyran, Jean-Robert and Rupert Sausgruber, "A Little Fairness May Induce a lot of Redistribution in Democracy," European Economic Review, 2006, 50 (2), 469-485.

Vlachos, Jonas, "Who Wants Political Integration? Evidence from the Swedish EU-Membership Referendum," Journal of Public Economics, 2004, 88 (7-8), 15891604.

Zucco, Cesar, "When Payouts Pay Off: Conditional Cash Transfers and Voting Behavior in Brazil 2002-10," American Journal of Political Science, 2013, 57 (4), $810-822$. 